\title{
Betonarme Kiriş ve Kolonların Tersinir Çevrimsel Yükler Altındaki Kesme Dayanımına Betonun Katkısı Üzerine Deneysel Bir inceleme
}

\author{
Cem AYDEMIR ${ }^{1}$ \\ Müberra ESER AYDEMİ ${ }^{2}$ \\ Güray ARSLAN ${ }^{3}$
}

ÖZ

Bu çalışmada betonun kesme dayanımına katkısı deneysel olarak incelenmiştir. İncelemeler, eğilme kırılmasıyla taşıma gücüne ulaşan toplam 12 adet kolon ve kiriş numunesiyle gerçekleştirilmiştir. Yön değiştiren ya da yön değiş̧irmeyen plastik mafsal davranışının söz konusu olduğu kiriş deney numuneleri için temel değişkenler; basınç dayanımı, enine donatı aralığı, plastik mafsal çalışma biçimi ve kesme açıklığının faydalı yüksekliğe oranıdır. Sabit eksenel yük ve yön değiştiren çevrimsel yerdeğiştirme altında zorlanan betonarme kolon numunelerinde ise temel değişkenler; eksenel yük düzeyi ve kesme açıklığının faydalı yüksekliğe oranıdır. Deney numunelerinde yerdeğiştirme talebine göre değişken olarak ortaya çıkan beton kesme katkısı, başta Türkiye Bina Deprem Yönetmeliği olmak üzere çeşitli tahmin modellerinin sonuçlarıyla karşılaştırılmalı olarak irdelenmiştir. Sınırlı sayıda karşılaştırma sonuçlarına göre, Türkiye Bina Deprem Yönetmeliği kabulleriyle belirlenen beton katkısının kiriş numunelerinde ihtiyatlı, kolon numuneleri için ise kapasitenin üzerinde sonuçlar verdiği saptanmıştır.

Anahtar Kelimeler: Kesme dayanımı, betonun kesme dayanımına katkıs1, kesme dayanımı-süneklik etkileşimi, yön değiştiren plastik mafsal, yön değiştirmeyen plastik mafsal.

\section{ABSTRACT \\ An Experimental Study on Concrete Contribution to Shear Capacity of RC Beams and Columns under Cyclic Loading}

In this study, concrete contribution to shear strength is experimentally investigated for RC beams and columns with flexural failure. For beam samples with reversing or non-reversing plastic hinge mechanism, the main variables are concrete compressive strength, transverse reinforcement spacing,

\footnotetext{
Not: Bu yazı

- Yayın Kurulu'na 21 Ekim 2020 günü ulaşmıştır. 13 Nisan 2021 günü yayımlanmak üzere kabul edilmiştir.

- 31 Temmuz 2022 gününe kadar tartışmaya açıktır.

- https://doi.org/10.18400/tekderg.814089

1 İstanbul Aydın Üniversitesi, İnşaat Mühendisliği Bölümü, İstanbul - cemaydemir@aydin.edu.tr https://orcid.org/0000-0003-4531-5084

2 İstanbul Aydın Üniversitesi, İnşaat Mühendisliği Bölümü, İstanbul - muberraaydemir@aydin.edu.tr https://orcid.org/0000-0002-4609-4845

3 Yıldız Teknik Üniversitesi, İnşaat Mühendisliği Bölümü, İstanbul - aguray@yildiz.edu.tr https://orcid.org/0000-0001-5004-8617
} 
type of plastic behavior and shear span / effective depth ratio. For column samples under constant axial load level and reversing cyclic loads, the considered variables are axial load level and shear span / effective depth ratio. Concrete contribution to shear strength, which varies with displacement demand, is compared with analytical results of different approaches involving the assumptions of Turkish Seismic Design Code. With the limited number of test samples, it is obtained that Turkish Seismic Design Code assumptions may provide conservative results for beam samples whereas remain unconservative for column samples.

Keywords: Shear strength, concrete contribution to shear strength, shear strength-ductility interaction, reversing plastic hinge, non-reversing plastic hinge.

\section{GíRiş}

Kesme ya da eğik çekme kırılması gevrek bir kırılmadır. Kesmeye karşı güvenlik, dayanımın, tasarım kuvvetinden $\left(\mathrm{V}_{\mathrm{d}}\right)$ eşit ya da büyük tutulmasıyla sağlanır. Deprem durumunda tasarım kuvvetinin $\left(\mathrm{V}_{\mathrm{e}}\right)$ saptanmasında kapasite tasarımı ilkesinden [1, 2 ve 3] yararlanılır. Eleman uçlarındaki eğilme momenti kapasitelerinin $\left(M_{p}\right)$ kullanıldı̆̆ bu uygulamayla, kesme kuvveti talebinin olası en büyük değeri elde edilerek [4, 5], güç tükenmesinin sünek olarak ortaya çıkması sağlanabilir.

Betonarme kesitlerin kesme dayanımı, beton katkısı $\left(\mathrm{V}_{\mathrm{c}}\right)$ ve kesme donatısı katkısının $\left(\mathrm{V}_{\mathrm{w}}\right)$ toplanmasıyla ifade edilir (6 9). Kesme donatısı katkısı, eğik kesme çatlağını kesen enine donatılarca karşılanan kesme kuvvetlerinin toplamıdır. Tasarım yönetmeliklerinde bu katkı, eğik kesme çatlağı açısının değişmediği $\left(45^{\circ}\right)$ varsayılarak [6, 7] ya da açıdaki değişim dikkate alınarak [8, 9] belirlenebilmektedir. Kesme dayanımına beton katkısı ise çatlamamış basınç bölgesinde beton, çekme bölgesinde boyuna donatının kaldıraç etkisi ve çatlak yüzeyinde agrega sürtünmesi tarafından karşılanan bileşenlerin toplamı olarak ifade edilebilir [10].

Çevrimsel yükle elastik ötesi davranışa zorlanan betonarme elemanlarda, kesme dayanımında, eğilme dayanımına nispeten daha hızlı bir azalma meydana gelir. Bu olgu, Şekil 1'de gösterilen ve kesme dayanımının süneklik ile etkileşiminin tanımlandığ kavramsal bir model [11] yardımıyla tartışılacaktır.

Şekilden de görüleceği üzere; kavramsal modelde, kapasite tasarımı ilkesi yardımıyla eğilme kapasitesine bağlı üç farklı kesme talebi $\left(\mathrm{V}_{\mathrm{e} 1}, \mathrm{~V}_{\mathrm{e} 2}, \mathrm{~V}_{\mathrm{e} 3}\right)$ örneklendirilmiştir. Diyagramda kesikli çizgiyle elemanın yerdeğiştirme sünekliğine $\left(\mu_{\Delta}\right)$ göre değişken varsayılan kesme kapasitesi $\left(\mathrm{V}_{\mathrm{c}}+\mathrm{V}_{\mathrm{w}}\right)$ gösterilmiştir. Elastik ötesi yerdeğiştirme talebi altında kesme dayanımının doğrusal azalarak, kalıcı bir dayanımda sabit varsayıldığı bu modelde: (a) akma öncesi kesme kırılmasının meydana geldiği gevrek kırılma durumu, (b) plastik yerdeğiştirme yapabilmesine karşın; elastik ötesi yerdeğiştirme kapasitesine ulaşmadan kesme kırılması durumu, (c) ise sünek eğilme kırılması durumudur. Modelin kavranması, depreme dayanıklı bina tasarım yönetmeliklerinde uygulanan kapasite tasarımı ilkesinin ve elastik ötesi davranışta bazı durumlarda betonun kesme dayanımına katkısının ihmal edilmesinin; (a) ve (b) türü gevrek kırılmaların önlenmesi, (c) türü sünek kırılma ile taşıma gücüne ulaşılması için yapılan uygulamalar olduğunu daha anlaşılır kılmaktadır.

Türkiye Bina Deprem Yönetmeliği ve ACI318-14'de [1 ve 6] betonarme kirişler için, sadece deprem yüklerinden oluşan kesme kuvvetinin depremli durumdaki toplam kesme 
kuvvetinin yarısından daha büyük olması; betonarme kolonlar için ise yukarıdaki şarta ek olarak aynı zamanda kolon eksenel yükünün $0.05 \mathrm{~A}_{\mathrm{c}} \mathrm{f}_{\mathrm{ck}}$ değerinin altında olması durumunda, betonun kesme dayanımına katkısını ihmal edilmektedir. Belirgin ve yüksek süneklik talebi altındaki betonarme elemanların kesme dayanımına betonun katkısı FEMA 356 [12] yönetmeliğinde de benzer yaklaşımla belirlenmektedir.

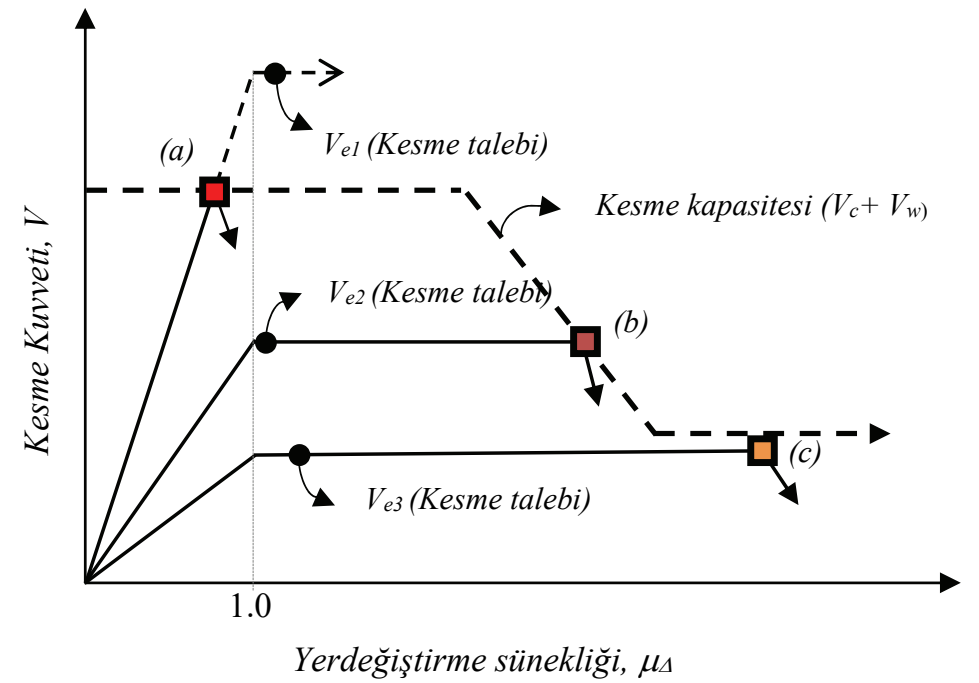

Şekil 1 - Kesme dayanımı-süneklik etkileşim modeli (ATC-6 [11])

Betonarme yapı elemanların elastik ötesi yerdeğiştirme talebine bağlı olarak kesme dayanımındaki azalmanın belirlenmesine yönelik birçok model geliştirilmiştir. Moehle vd. [13] ve Sezen ve Moehle [14] betonarme kolonların kesme dayanımını yerdeğiştirme süneklik oranı talebiyle ilişkilendirmiştir. Bu ilişkide betonun ve enine donatının kesme dayanımlarına katkıları için benzer katsayılar kullanılmaktadır. Wong vd. [15], Aschheim ve Moehle [16], Priestly vd. [17] ve Pérez ve Pantazopoulou [18] tarafından geliştirilen modellerde de betonun kesme dayanımına katkısı, yerdeğiştirme süneklik oranı talebine bağlı biçimde ifade edilmektedir. Lee ve Watanabe [19] tarafindan geliştirilen modelde kesme dayanımındaki azalma, betonarme kirişlerde boyuna donatı akması sonrası, uygunluk şartlarına bağlı biçimde kafes kiriş benzeşimi yardımıyla ifade edilmektedir. Elwood ve Moehle [20] yapıların şekil değiştirmeye göre tasarımı ve mevcut yapıların performans değerlendirmesinde kat öteleme oranına göre değişken bir model geliştirmiştir. Arslan [21], betonun kesme dayanımına katkısının olmadığı göçme hasar sınır durumu için enine donatının kesme dayanımına katkısının belirlenebilmesi için bir model önermiştir. Kowalsky ve Priestley [22], betonarme kolonların kesme dayanımını, kolon narinlik oranı, boyuna donatı oranı ve yerdeğiştirme süneklik oranına göre değişken olarak ifade etmişlerdir. Muttoni [23], betonun kesme dayanımına katkısını kontrol derinliğindeki boyuna birim şekildeğiştirme talebine bağlı biçimde ifade ederek, geliştirilen bağıntının sonuçlarını deneysel sonuçlar ile karşılaştırmıştır. 
$\mathrm{Bu}$ çalışmada, çevrimsel yükler altında eğilme kırılması ile taşıma gücüne ulaşan deney numunelerinde kesme dayanımına beton katkısı incelenmiştir. $\mathrm{Bu}$ incelemelerde kolon ve kiriş deney numunelerinde meydan gelen kesme donatısı ve beton katkılarının artan yerdeğiştirme talebine göre değişimleri diyagramlar üzerinde gösterilmiştir. Ayrıca deney numunelerinde yerdeğiştirme talebine göre değişken olarak ortaya çıkan beton kesme katkısı, başta Türkiye Bina Deprem Yönetmeliği olmak üzere çeşitli tahmin modellerinin sonuçlarıyla karşılaştırılmalı olarak irdelenmiştir.

\section{DENEY PROGRAMI}

\subsection{Deney Numuneleri}

İstanbul Aydın Üniversitesi İnşaat Mühendisliği Laboratuvarında üretilerek test edilen kiriş deney numunelerinin geometrisi ve donatı detayları Şekil 2'de gösterilmiş, malzeme özellikleri ise Çizelge 1'de özetlenmiştir. Kolon numuneleri için benzer veriler Şekil 3 ve Çizelge 2'de verilmiştir.
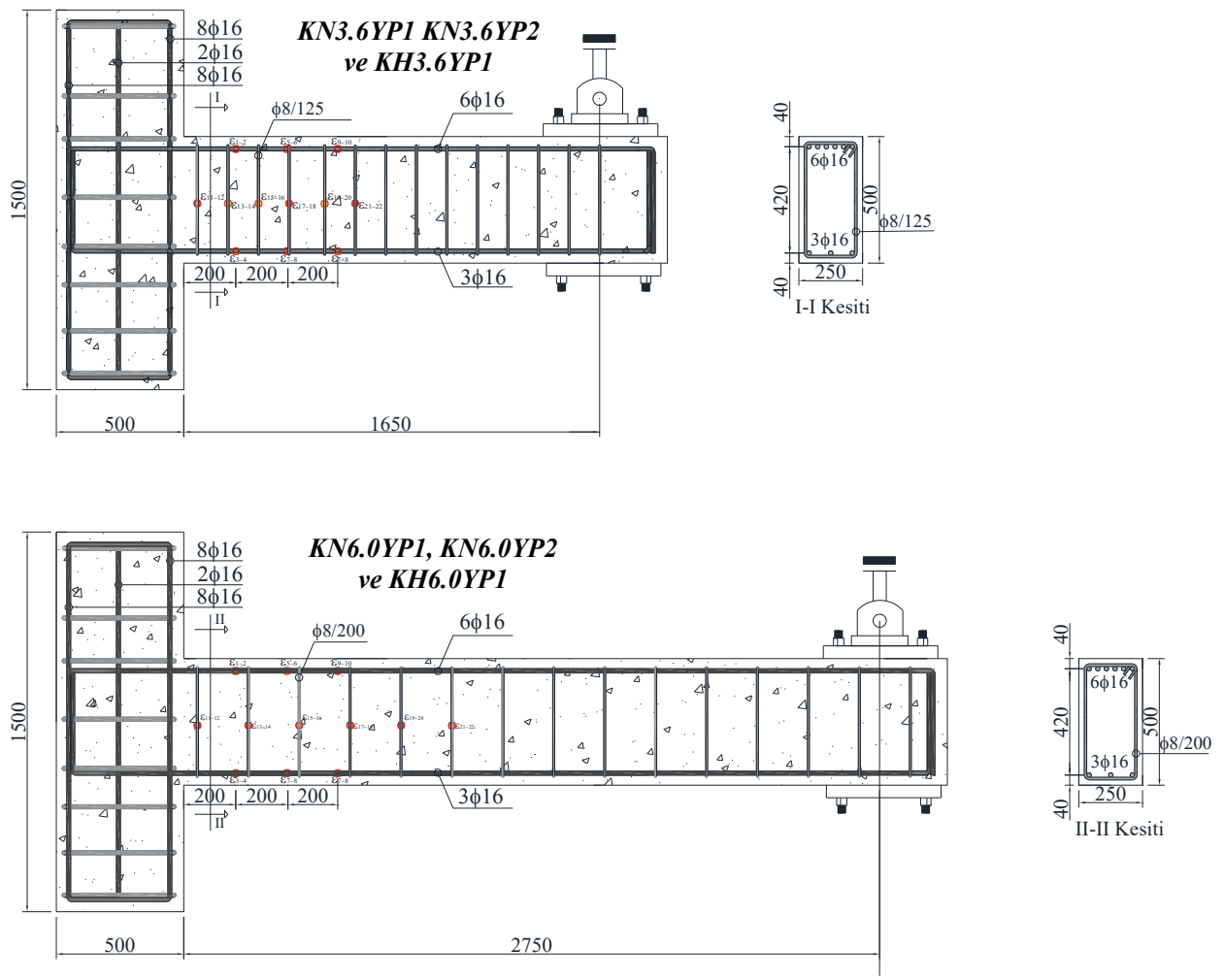

Şekil 2 - Kiriş deney numunelerinin detayları (tüm boyutlar mm) ve birim şekildeğiştirme ölçerlerin konumları 
Çizelge 1 - Kiriş deney numunelerinin malzeme özellikleri

\begin{tabular}{|c|c|c|}
\hline \multirow[b]{2}{*}{ Parametre } & \multicolumn{2}{|c|}{ Kiriş Deney Numuneleri } \\
\hline & $\begin{array}{l}\text { KN3.6YP1 } \\
\text { KN3.6YP2 } \\
\text { KH3.6YP1 }\end{array}$ & $\begin{array}{l}\text { KN6.0YP1 } \\
\text { KN6.0YP2 } \\
\text { KH6.0YP1 }\end{array}$ \\
\hline Beton basınç dayanımı ${ }^{(\mathrm{a})}, \mathrm{f}_{\mathrm{co}}(\mathrm{MPa})$ & $\begin{array}{l}45.6 \\
39.7 \\
64.4\end{array}$ & $\begin{array}{l}48.6 \\
44.5 \\
65.4\end{array}$ \\
\hline $\begin{array}{l}\text { Boyuna donatı akma dayanımı }{ }^{(\mathrm{b})}, \mathrm{f}_{\mathrm{y}} \\
\text { (MPa) }\end{array}$ & 498 & 490 \\
\hline $\begin{array}{l}\text { Enine donatı akma dayanımı }{ }^{(\mathrm{b})}, \mathrm{f}_{\mathrm{yw}} \\
(\mathrm{MPa})\end{array}$ & 597 & 597 \\
\hline \multicolumn{3}{|c|}{$\begin{array}{l}\text { (a) } 150 \mathrm{~mm} / 300 \mathrm{~mm} \text { boyutlarındaki silindir beton numuneden TS EN } 12390-3 \text { standardina uygun olarak deney günü elde edilen } \\
\text { basinç dayanıml. } \\
\text { (b) Boyuna ve enine donatıdan alınan numunelerinden TS EN ISO 6892-1 standardina uygun olarak elde edilen akma dayaniml. }\end{array}$} \\
\hline
\end{tabular}

SN3.5/0.10YP1, SN3.5/0.20YP1 ve SN3.5/0.35YP1

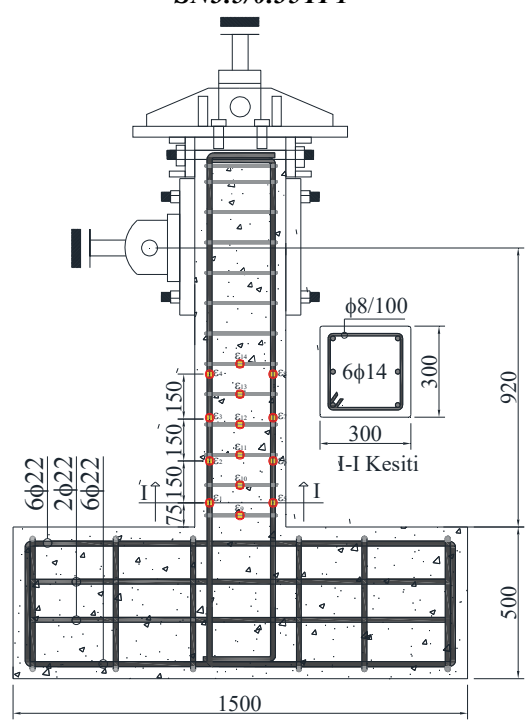

SN6.0/0.10YP1, SN6.0/0.20YP1 ve

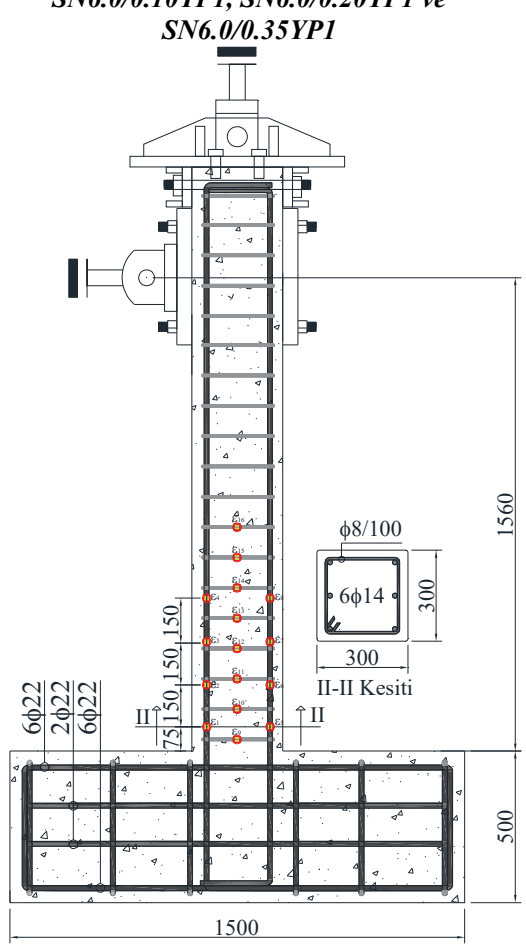

Şekil 3 - Kolon deney numunelerinin detayları (tüm boyutlar mm) ve birim şekildeğiştirme ölçerlerin konumları 
Çizelge 2 - Kolon deney numunelerinin malzeme özellikleri ve eksenel yük düzeyleri

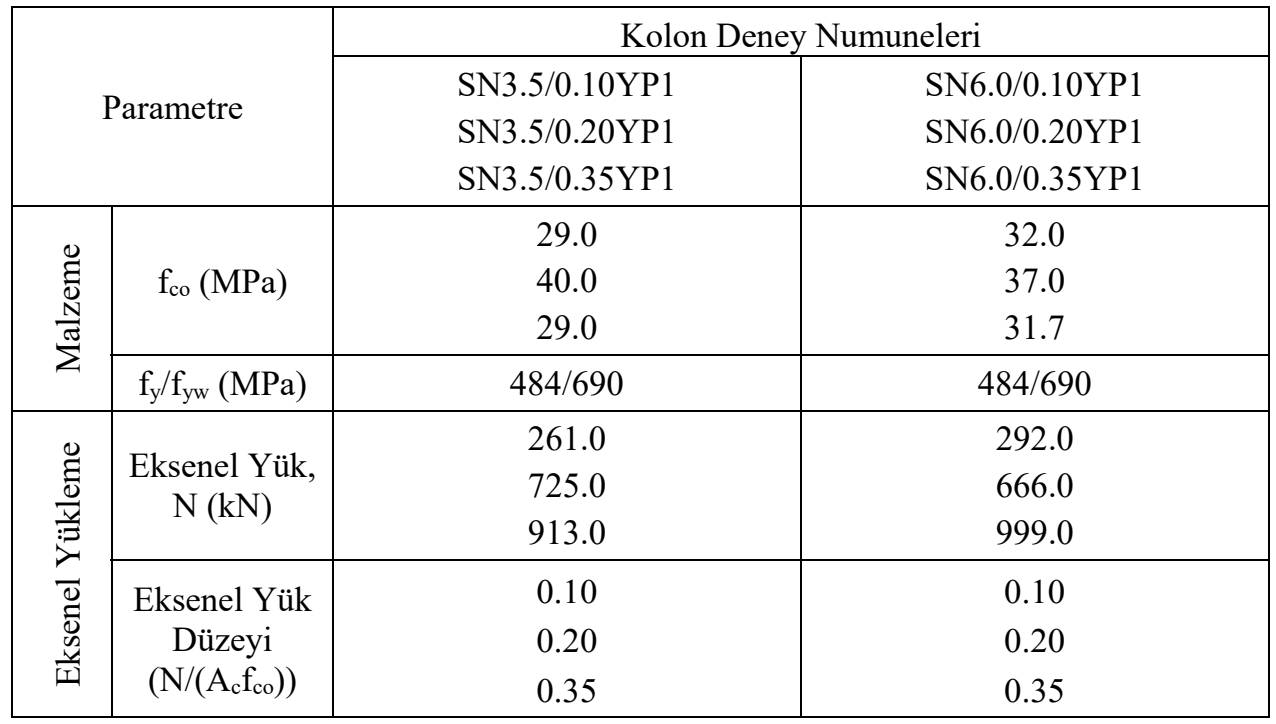

Deney programındaki kiriş numuneler, çevrimsel yükleme altında potansiyel plastik mafsal bölgelerinde tabla betonunun çekme etkisiyle çatlamış olacağı kabulüyle, çift donatılı dikdörtgen kesit olarak tasarlanmıştır [24, 25, 26]. Ayrıca tabla betonunun çekmeye zorlanması durumunda, döşeme donatılarının eğilme kapasitesini arttırıcı etkisi [27] göz önüne alınmamıştır. Kiriş deney numuneleri $(\mathrm{K})$, beton basınç dayanımı (N: Normal, H: Yüksek), a/d oranı (3.6 ya da 6.0) ve yükleme geçmişi (YP1 ya da YP2); kolon numuneleri ise (S), a/d oranı (3.5 ya da 6.0$)$ ve eksenel yük düzeyi $(0.10,0.20$ ve 0.35$)$ farklılığına göre isimlendirilmiştir.

\subsection{Deney Düzeneği}

Kiriş deney düzeneği şematik olarak Şekil 4'de gösterilmiştir. Yükleme öncesi deney numunesi laboratuvar kuvvetli döşemesine sabitlenerek, mesnette dönme ve yerdeğiştirme tutulu hale getirilmiştir. Deney düzeneğinde yükleme geçmişi, $500 \mathrm{kN} / \pm 250 \mathrm{~mm}$ kapasiteli servo-hidrolik bir aktivatör ile uygulanmaktadır. Deney düzeneğinde mesnet bölgesi gerçek bir yapıda rijit bir kolon, konsol kiriş numunesine bağlanan aktivatörün yük uygulama merkezi ise kirişin moment sıfır noktası ile benzeştirilebilir.

Kolon deney düzeneği ise Şekil 5'de verilen şematik çizimden görülebilir. Kolon numuneleri deney öncesi laboratuvar kuvvetli döşemesine sabitlenerek, mesnet bölgesinde dönme ve yerdeğiştirme tutulu hale getirilmiştir. Konsol kolon numunesinin mesnedi gerçek bir yapıda rijit bir temel, yükleme geçmişinin uygulama noktası ise gerçek bir yapıda moment sıfır noktası ile benzeştirilebilir. Kolon numunelere uygulanan yatay yük yerdeğiştirme kontrolünde, eksenel yük ise kuvvet kontrolünde uygulanmıştır. Eksenel yük verici pistonun numune ile bağı mafsallı, çerçeveye ise kayıcı ankastredir. Bu bağ yapısı konsol ucundaki yatay yerdeğiştirme, düşey yerdeğiştirme ve dönmenin serbest, eksenel 
yük verici pistonun doğrultusunun ise sabit kalmasını sağlamaktadır [28]. Bu bağlantının daha iyi anlaşılabilmesi için şematik deney düzeneği gösteriminde konsol ucundan yer değiştirmiş bir kolon numunesi üzerinde yapılmıştır.

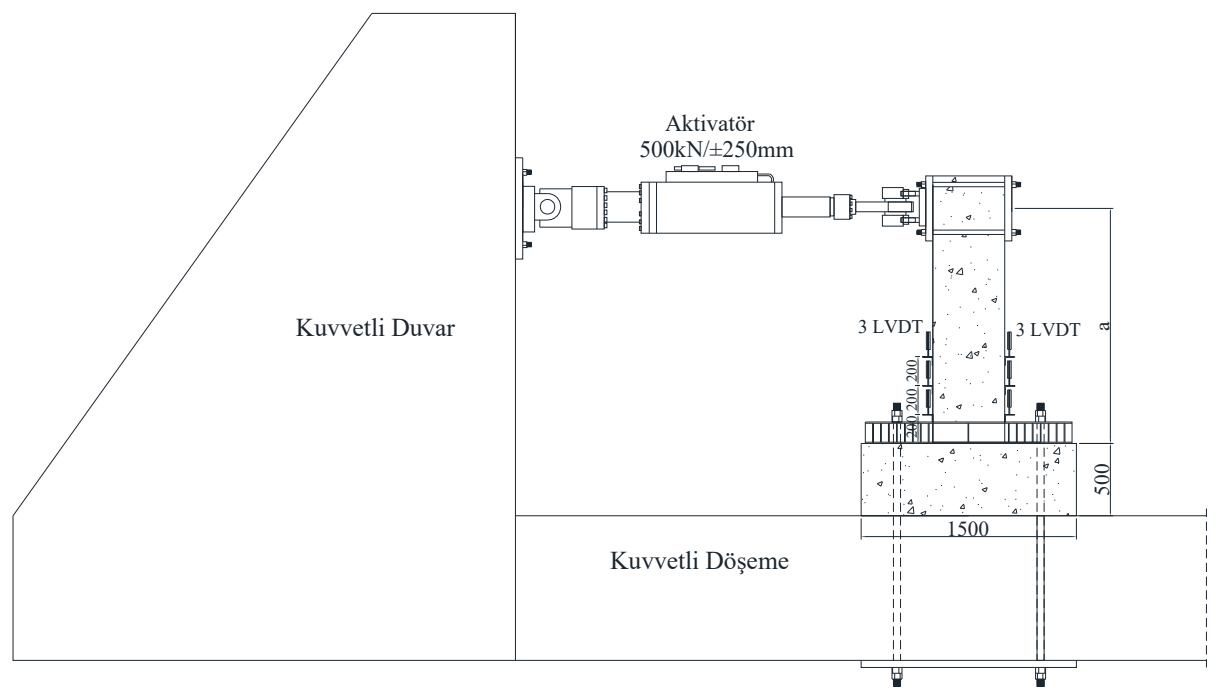

Şekil 4 - Kiriş deney numunelerine uygulanan deney düzeneği

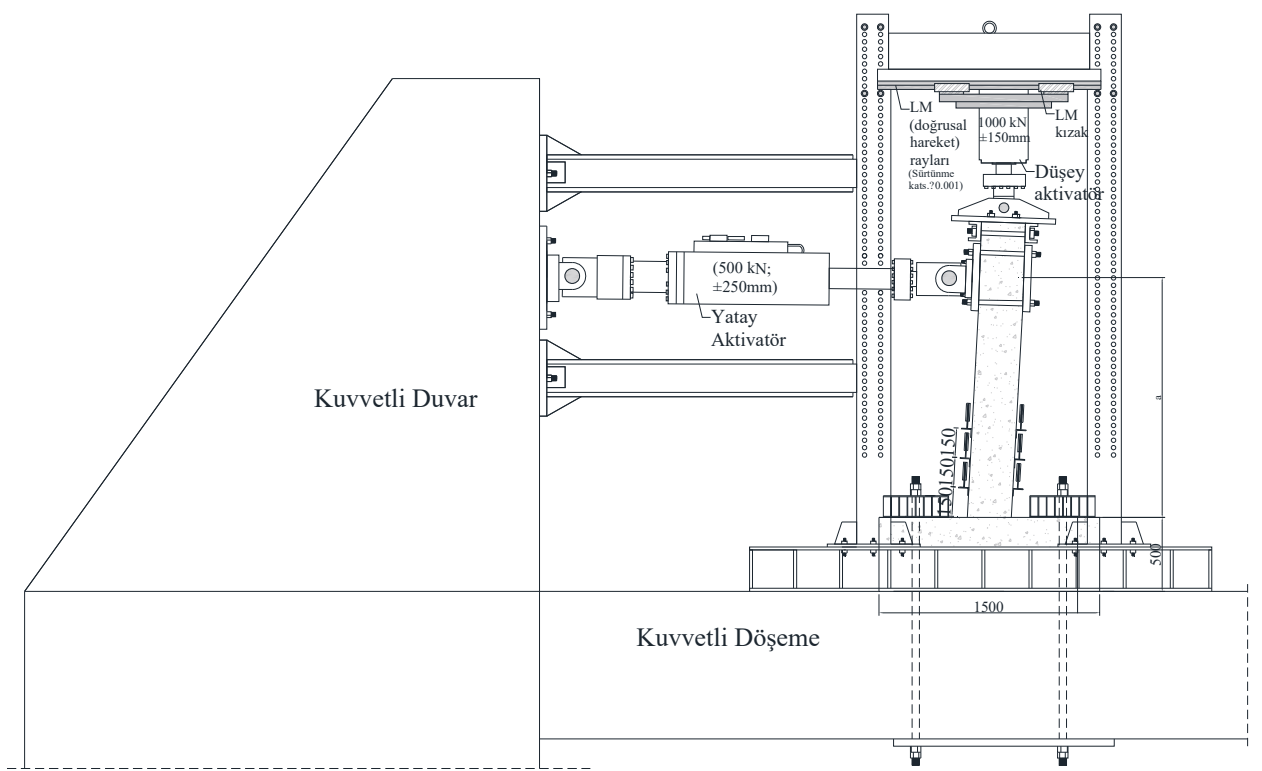

Şekil 5 - Kolon deney numunelerine uygulanan deney düzeneğinin yer değiştirmiş bir kolon numunesi üzerinde şematik gösterimi 
Deney düzeneğinde boyuna ve enine donatılardaki birim şekil değiştirmeler, potansiyel plastik mafsal bölgesinde 3 farklı düzlemde boyuna birim şekildeğiştirme dağılımlarının belirlenebilmesi için birim şekildeğiştirme (Şekil 2 ve Şekil 3) ve yerdeğiştirme ölçerler (Şekil 4 ve Şekil 5) kullanılmıştır. Deney verilerinin toplanmasında 30 kanallı bir veri toplayıcından yararlanılmıştır.

\subsection{Yükleme Geçmişleri}

Çalışmada YP1, numune mesnet bölgelerinde yön değiştiren plastik mafsal davranış1 meydana getiren yükleme geçmişi, YP2 ise numune mesnet bölgelerinde yön değiştirmeyen plastik mafsal davranışı meydana getiren yükleme geçmişi için kullanılan isimlendirmedir.

Şekil 6'da yerdeğiştirme kontrolünde numunelere uygulanan YP1 isimli yükleme geçmişi gösterilmiştir. YP1 yükleme geçmişinde hedef yerdeğiştirme, numunelerin analitik akma yerdeğiştirmelerine oranları ile tanımlanmaktadır. Bu oranların 0.5 ve üzerindeki değerleri için hedef yerdeğiştirme 3 tekrarlı olarak uygulanmıştır. Kiriş deney numunelerinde simetrik olmayan donatı düzeni nedeniyle, kiriş numuneleri için YP1 yükleme geçmişinin belirli bir çevrimdeki pozitif ve negatif hedef yerdeğiştirmeler birbirinden farklı olabilmektedir.

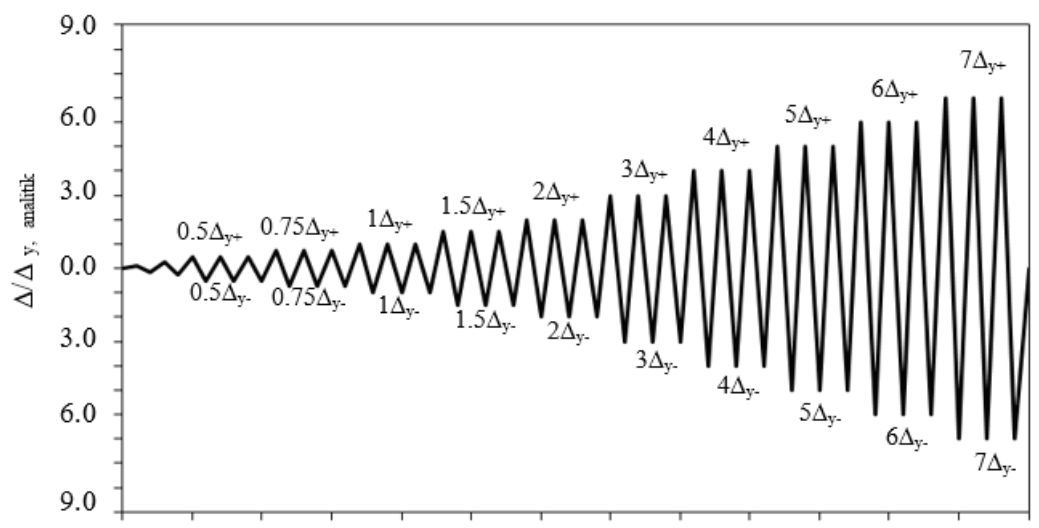

Şekil 6 - YP1 yükleme geçmişi [24, 25]

Şekil 7.b'de, Düşey yüklerin tek yönlü eğilme etkisinin (kuvvet kontrolüyle) ve depremin tersinir etkisinin (yerdeğiştirme kontrolüyle) birlikte uygulandığ1 YP2 yükleme geçmişinin tipik tekrarlı çevrimi şematik olarak gösterilmiştir. Yerdeğiştirme kontrolü aşamasında özdeş hedef yerdeğiştirme uygulanan YP1 ve YP2 yüklemeleri, aralarındaki farklılı̆̆ın daha belirgin gösterilmesi adına yan yana gösterilmiştir (Şekil 7.a ve 7.b). YP2 yüklemesinekuvvet kontrolünde- işletme yükünün $\left(\mathrm{F}_{\mathrm{G}+\mathrm{Q}}\right)$ uygulanmasıyla başlanır. YP2 çevrimsel yüklemesinin bir çevrimi için izlenen adımlar [29] şu şekilde özetlenebilir. Kuvvet kontrollü işletme yükü sabit tutulurken ilave olarak yerdeğiştirme kontrolünde pozitif bir hedef yerdeğiştirme uygulanır. İlave yerdeğiştirme hedef yerdeğiştirmeye ulaşıldığında, düşey işletme yükünün yön değiştirmesi kuvvet kontrollünde uygulanmaktadır. Bu adım 
başta verilen işletme yükünün boşaltılması olarak da ifade edilebilir ama numune üzerinde hala ilave bir pozitif yer değiştirme vardır. Kuvvet kontrollü adım sonrası ilave olarak, yerdeğiştirme kontrolünde negatif bir hedef yerdeğiştirme uygulanır. İlave yerdeğiştirme hedef yerdeğiştirmeye ulaş̧ı̆gında, düşey işletme yükü kuvvet kontrolünde YP2'nin tipik bir çevrimi tamamlanır. Şekil 7.b'de tipik tekrarlı çevrimde düşey işletme yükünün yüklenip boşaltıldığı tekrarlı yükleme çevrimleri, elastik ötesi aşamada numune rijitliğinin bir önceki adıma göre azalacağı ve dolayısıyla numunenin yerdeğiştirme cevabının artacağı varsayılarak, şematik olarak çizilmiştir. YP2 yüklemesinde düşey işletme yükün uygulama değeri, kesiti akma limit duruma getiren yükün yarısı olarak dikkate alınmıştır [29].

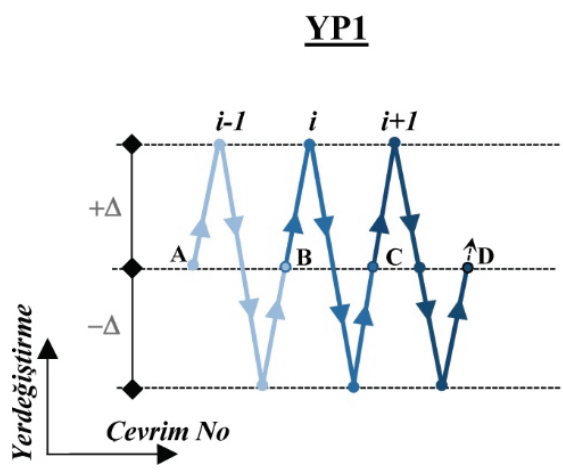

a) Yerdeğiştirme kontrollü yükleme geçmişi için tipik tekrarl çevrim (YPI)

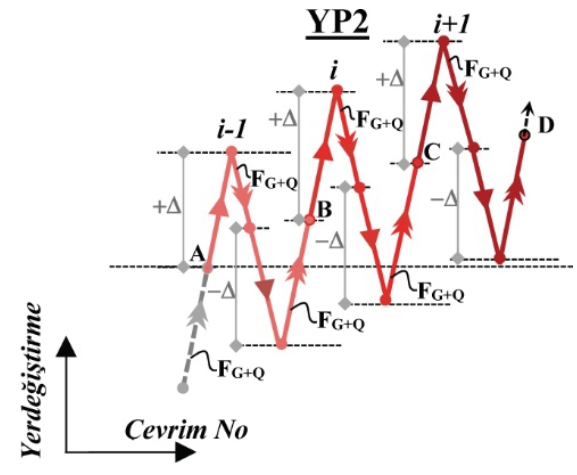

b) Kuvvet ve yerdeğiştirme kontrollü yükleme geçmişine için tipik tekrarlı çevrim (YP2)

Şekil 7 - Yükleme geçmişlerinin tipik bir çevrimleri (a) YP1, Yerdeğiştirme kontrollü yükleme (standart çevrimsel yükleme) (b) $\mathbf{Y P 2}$, Kuvvet ve yerdeğiştirme kontrolünün birlikte uygulandı̆̆ yükleme (Belirgin düssey yük hali için çevrimsel yükleme izlencesi [29])

\section{DENEYSEL SONUÇLAR VE KARŞILAŞTIRMALAR}

\subsection{Kırılma Biçimleri}

Numunelere uygulanan deneysel eğilme momenti ve kesme kuvvetinin, numunelerin analitik eğilme momenti ve kesme kuvveti taşıma güçleriyle karşılaştırılması ve kırılma biçimleri Çizelge 3'de özetlenmiştir. Çizelgede verilen analitik taşıma güçleri, deneysel malzeme dayanımları kullanılarak, TS500-2000'e göre hesaplanan karakteristik taşıma güçleridir $\left(\gamma_{\mathrm{c}}=1\right.$ ve $\left.\gamma_{\mathrm{s}}=1\right)$.

Deney numunelerinin tamamında başlangıç hasarı, numune eksenine dik konumda gelişen eğilme çatlaklarıdır. Yerdeğiştirme genliği talebinin artan değerleri için eğilme çatlaklarının aralıkları azalmaktadır. YP1 yükleme geçmişinin uygulandığı numunelerde yön değiştiren plastik davranış nedeniyle bu çatlaklar numunelerin her iki yüzünde de meydana gelmekte ve çatlak oluşumuyla numunenin her iki eğilme doğrultusunda da eğilme rijitliğinde belirgin bir azalma görülmektedir. Deney numunelerinin eğilme rijitliğinde belirgin bir değişime neden olan bir diğer hasar göstergesi de çekme bölgesindeki boyuna donatının akmasıdır. Deney sırasında bu durum donatılara yerleştirilen birim şekildeğiştirme ölçerlerle saptanmıştır. Çekme donatısı akma durumu, YP1 yükleme profilinin uygulandığı 
numunelerin tamamında her iki yüzde (yön değiştiren plastik mafsal davranış1), YP2 yükleme profilinin uygulanan numunelerde ise sadece bir yüzdeki (yön değiştirmeyen plastik mafsal davranışı) boyuna donatılarda meydana gelmiştir. Deney numunelerinin tamamında betonda ilk ezilme başlangıcı (örtü betonda ezilme başlangıcı), boyuna donatıda akma meydana geldikten sonra gerçekleşmiştir. Bu bağlamda çizelge 3'de verilen ve kapasite karşılaştırması ile belirlenen kırılma biçimleri ile deneysel gözlemler uyumlu biçimde gerçekleştiği söylenebilir. SN6.0/0.35YP1 kolonu dışındaki tüm numuneler için boyuna donatı akması sonrası eğik çatlak oluşumu gözlenmiştir. Eğik çatlak oluşumunun gözlendiği yerdeğiştirme talebi numuneden numuneye değişkenlik göstermektedir. Deney numunelerinin tamamında elastik ötesi davranış bölgesinde yük taşıma gücünde belirgin azalma basınç bölgesindeki boyuna donatıların burkulmasıyla ortaya çıkmaktadır. YP1 yükleme profilinin uygulandığı kiriş numunelerinde basınç donatısı burkulması sonrası kiriş alt yüzüne karşı gelen bu bölgenin çekmeye zorlanması durumunda boyuna donatılarda kopma da gözlenmiştir. Ayrıca SN6.0/0.35YP1 kolonunda basınç donatısı burkulmasının meydana geldiği yerdeğiştirmenin tekrarlı uygulaması sırasında, numunenin eksenel yük taşıma kapasitesinde belirgin azalma meydana geldiğinden, yüklemeye son verilmiştir.

Çizelge 3 - Deney numunelerinin eğilme ve kesme kapasitelerin karşılaştırılması

\begin{tabular}{|c|c|c|c|c|c|c|}
\hline \multirow{2}{*}{ Deney Numunesi } & \multicolumn{3}{|c|}{ Seri } & \multirow{2}{*}{$\mathrm{M}_{\text {maks }}{ }^{\mathrm{a}} / \mathrm{M}_{\mathrm{n}}^{\mathrm{b}}$} & \multirow{2}{*}{$\mathrm{V}_{\text {maks }}{ }^{\mathrm{c}} / \mathrm{V}_{\mathrm{n}}{ }^{\mathrm{d}}$} & \multirow{2}{*}{$\begin{array}{l}\text { Kirılma } \\
\text { biçimi }^{\mathrm{e}}\end{array}$} \\
\hline & TYPM $^{1}$ & $\mathrm{EYDB}^{2} 5^{2}$ & $\mathrm{YDAKU}^{3}$ & & & \\
\hline SN3.5/0.10YP1 & $\mathrm{x}$ & $\sqrt{ }$ & $\sqrt{ }$ & 1.39 & 0.45 & $\mathrm{E} / \mathrm{C}$ \\
\hline SN3.5/0.20YP1 & $\mathrm{x}$ & $\sqrt{ }$ & $\sqrt{ }$ & 1.13 & 0.20 & $\mathrm{E} / \mathrm{C}$ \\
\hline SN3.5/0.35YP1 & $\mathrm{x}$ & $\sqrt{ }$ & $\sqrt{ }$ & 1.10 & 0.46 & $\mathrm{E} / \mathrm{C}$ \\
\hline SN6.0/0.10YP1 & $\mathrm{x}$ & $\sqrt{ }$ & $\sqrt{ }$ & 1.08 & 0.23 & $\mathrm{E} / \mathrm{C}$ \\
\hline SN6.0/0.20YP1 & $\mathrm{x}$ & $\sqrt{ }$ & $\sqrt{ }$ & 1.36 & 0.56 & $\mathrm{E} / \mathrm{C}$ \\
\hline SN6.0/0.35YP1 & $\mathrm{x}$ & $\sqrt{ }$ & $\sqrt{ }$ & 1.14 & 0.25 & $\mathrm{E} / \mathrm{C}$ \\
\hline KN3.6YP1 & $\mathrm{x}$ & - & $\sqrt{ }$ & $1.02 / 1.05$ & $0.72 / 0.38$ & $\mathrm{E} / \mathrm{C}$ \\
\hline KH3.6YP1 & $\mathrm{x}$ & - & $\sqrt{ }$ & $1.03 / 1.04$ & $0.75 / 0.38$ & $\mathrm{E} / \mathrm{C}$ \\
\hline KN3.6YP2 & $\sqrt{ }$ & - & $\sqrt{ }$ & 1.11 & 0.49 & $\mathrm{E} / \mathrm{C}$ \\
\hline KN6.0YP1 & $\mathrm{x}$ & - & $\mathrm{x}$ & $1.01 / 1.04$ & $0.69 / 0.37$ & $\mathrm{E} / \mathrm{C}$ \\
\hline KH6.0YP1 & $\mathrm{x}$ & - & $\mathrm{x}$ & $1.01 / 1.03$ & $0.70 / 0.37$ & $\mathrm{E} / \mathrm{C}$ \\
\hline KN6.0YP2 & $\sqrt{ }$ & - & $\mathrm{x}$ & 1.04 & 0.35 & $\mathrm{E} / \mathrm{C}$ \\
\hline $\begin{array}{l}{ }^{1} \text { Tersinir tekrarl yüh } \\
{ }^{2} \text { Eksenel yüklü elemo } \\
{ }^{3} 2007 \text { Tarihli Depre } \\
\text { koşullarına uyum } \\
{ }^{a} \text { Deneysel yüklemede } \\
{ }^{b} \text { Deneysel malzeme } \\
{ }^{c} \text { Deneysel yüklemede } \\
{ }^{d} \text { Deneysel malzeme } \\
V_{c}>0 \Rightarrow V_{n}=V_{c}+V_{w} \\
{ }^{e} \text { E: Ĕ̆ilme, Ç: çekm }\end{array}$ & $\begin{array}{l}\text { ede plastik } \\
\text { rda, eksene } \\
\text { ölgelerinde } \\
\text { AKU). } \\
\text { ülen eğilm } \\
\text { ınımlarına } \\
\text { ülen kesme } \\
\text { ınımlarına } \\
, 2,7] .\end{array}$ & $\begin{array}{l}\text { afsal bölgesin } \\
\text { ük düzeyinin } \\
\text { apılacak Bina } \\
\text { nomentinin en } \\
\text { re hesaplana } \\
\text { uvvetinin en b } \\
\text { re hesaplana }\end{array}$ & 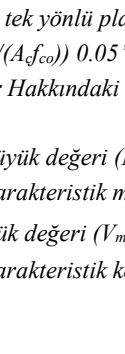 & $\begin{array}{l}\text { mafsal (TYPM } \\
\text { büyük olması } \\
\text { etmelikte [2] to } \\
\text { ent kapasitesi } \\
=\text { Maks }(V)) \text {. } \\
\text { e kuvveti taşım }\end{array}$ & $\begin{array}{l}\text { vranışl. } \\
\text { nu (EYDB05). } \\
\text { anan enine don } \\
1,2,7] . \\
\ddot{u}\left(V_{c}=0 \Rightarrow V_{n}=\right.\end{array}$ & \\
\hline
\end{tabular}




\subsection{Eğik Çatlama Dayanımı, $V_{\text {cr }}$}

Deney numunelerin eğik çatlama dayanımları $\left(\mathrm{V}_{\mathrm{cr}}\right)$ ile eğik çatlak oluşumunun gözlendiği yerdeğiştirme süneklik oranları $\left(\mu_{\Delta, v_{\text {cr }}}\right)$ Çizelge 4 'de özetlenmiştir. Deney sırasında numunelerdeki eğik çatlak oluşumu, yerdeğiştirme yükleme geçmişinin hedef maksimum değerine erişildiği her bir yükleme adımında yapılan görsel inceleme ile tespit edilmiştir.

\section{Çizelge 4 - Deney numunelerinin eğik çatlama dayanımları}

\begin{tabular}{|c|c|c|c|c|c|}
\hline \multirow{2}{*}{ Deney Numunesi } & \multicolumn{3}{|c|}{ Seri } & \multirow{2}{*}{$V_{c r}{ }^{\mathrm{a}}$} & \multirow{2}{*}{$\mu_{\Delta, \mathrm{V}_{\mathrm{cr}}}{ }^{\mathrm{b}}$} \\
\hline & TYPM $^{1}$ & $\mathrm{EYDB}^{2} 5^{2}$ & YDAKU $^{3}$ & & \\
\hline SN3.5/0.10YP1 & $\mathrm{x}$ & $\sqrt{ }$ & $\sqrt{ }$ & 108.0 & 1.0 \\
\hline $\mathrm{SN} 3.5 / 0.20 \mathrm{YP} 1$ & $\mathrm{x}$ & $\sqrt{ }$ & $\sqrt{ }$ & 135.1 & 1.1 \\
\hline $\mathrm{SN} 3.5 / 0.35 \mathrm{YP} 1$ & $\mathrm{x}$ & $\sqrt{ }$ & $\sqrt{ }$ & 161.2 & 1.1 \\
\hline SN6.0/0.10YP1 & $\mathrm{x}$ & $\sqrt{ }$ & $\sqrt{ }$ & 53.5 & 2.3 \\
\hline SN6.0/0.20YP1 & $\mathrm{x}$ & $\sqrt{ }$ & $\sqrt{ }$ & 65.6 & 2.0 \\
\hline SN6.0/0.35YP1 & $\mathrm{x}$ & $\sqrt{ }$ & $\sqrt{ }$ & --- & --- \\
\hline KN3.6YP1 & $\mathrm{x}$ & - & $\sqrt{ }$ & $155.8 /-82$ & $1.26 / 3.4$ \\
\hline KH3.6YP1 & $\mathrm{x}$ & - & $\sqrt{ }$ & $159.4 /-78.5$ & $1.61 / 4.0$ \\
\hline KN3.6YP2 & $\sqrt{ }$ & - & $\sqrt{ }$ & 149.7 & 2.17 \\
\hline KN6.0YP1 & $\mathrm{x}$ & - & $\mathrm{x}$ & 87/--- & 1.67/--- \\
\hline KH6.0YP1 & $\mathrm{x}$ & - & $\mathrm{x}$ & $94.9 /-50.0$ & $1.78 / 4.44$ \\
\hline KN6.0YP2 & $\sqrt{ }$ & - & $\mathrm{x}$ & 83.47 & 1.64 \\
\hline $\begin{array}{l}{ }^{1} \text { Tersinir tekrarl yük } \\
{ }^{2} \text { Eksenel yüklü elema } \\
{ }^{3} \text { 2007 Tarihli Depre } \\
\text { koşullarına uyum } \\
{ }^{a} \text { Eğik çatlak gözlemi } \\
{ }^{b} \text { Eğik çatlak gözlemi }\end{array}$ & $\begin{array}{l}\text { nede plastik } \\
\text { Irda, eksen } \\
\text { ölgelerind } \\
\text { AKU). } \\
\text { ki deneysel } \\
\text { ki yerdeğis }\end{array}$ & $\begin{array}{l}\text { afsal bölgesin } \\
\text { ük düzeyinin } \\
\text { aplacak Bina } \\
\text { sme yükü ( } V_{c \text { c }} \\
\text { menin akmay }\end{array}$ & $\begin{array}{l}\text { tek yönlü pla } \\
\left./\left(A_{c} f_{c k}\right)\right) 0.05, \\
\text { Hakkindaki } \\
\text { değiştirmesine }\end{array}$ & $\begin{array}{l}\text { sal }(\text { TYPM }) \text { dav } \\
\text { ik olmast durum } \\
\text { likte [2] tanımlo } \\
\left.\mu_{\Delta, V_{c r}}=\Delta_{V_{c l}} / \Delta_{y}\right)\end{array}$ & tı aralık \\
\hline
\end{tabular}

Eğik çatlama dayanımının eğik çatlak gözlenen süneklik oranı talebiyle değişimleri kiriş numuneleri için Şekil 8'de, kolon numuneleri için ise Şekil 9'da gösterilmiştir. Şekillerden de görüleceği üzere; a/d oranının artması, -bilindiği gibi- eğik çatlama dayanımında azalma meydana getirmesinin yanında, eğik çatlak oluşumu gözlenen yerdeğiştirme süneklik oranını da arttırmaktadır. Bu artış kiriş numunelerinde boyuna donatı oranının azalması ve basınç donatısı oranının artmasıyla, kolon numunelerinde ise eksenel yük seviyesinin azalmasıyla belirginleşmektedir. Bir başka ifadeyle, kesme açıklığının artması ve/veya eğilme davranışında tarafsız eksen derinliğini azalmasıyla; eğik çatlak oluşumunun gözlendiği yerdeğiştirme süneklik oranı arttığı, numunenin kesme dayanımının ise azaldığ1 söylenebilir. 
Betonarme Kiriş ve Kolonların Tersinir Çevrimsel Yükler Altındaki Kesme ...

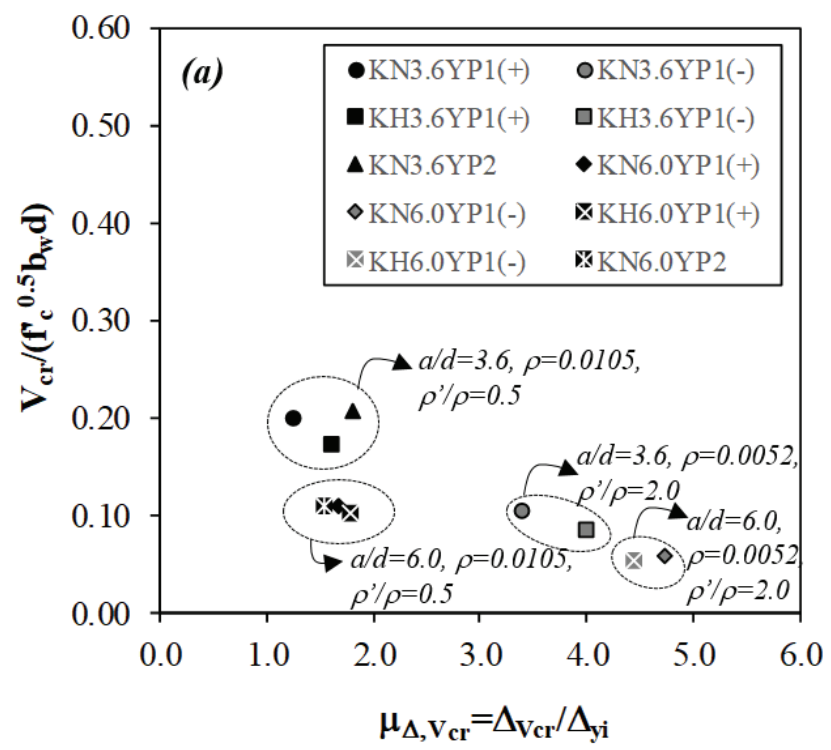

Şekil 8 - Kiriş numunelerinde eğik çatlama dayanımının ĕ̌ik çatlak oluşumunun gözlendiği yerdeğiştirme süneklik oranılla etkileşimi

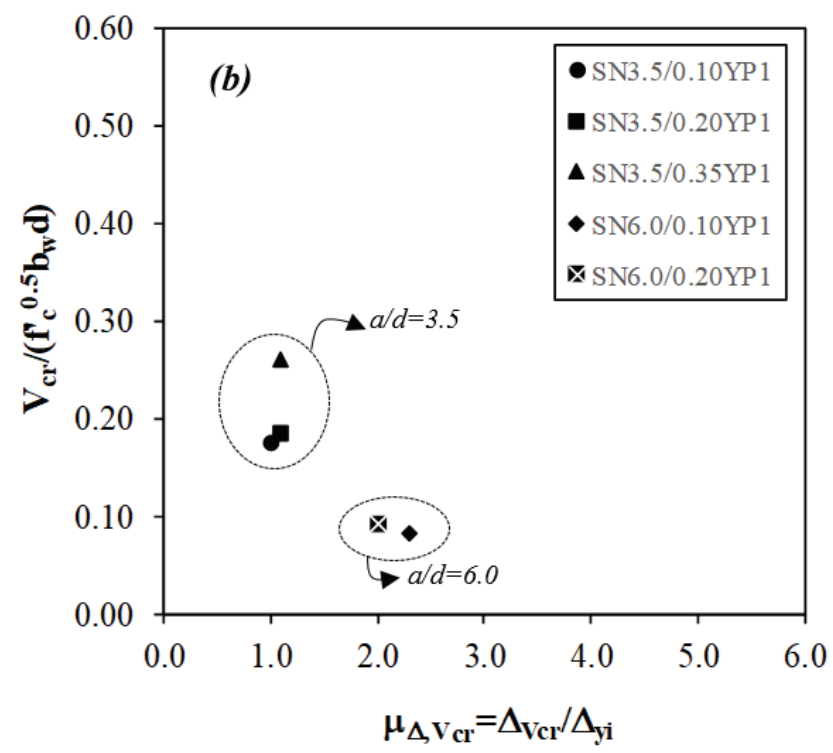

Şekil 9 - Kolon numunelerinde eğik çatlama dayanımının eğik çatlak oluşumunun gözlendiği yerdeğiştirme süneklik oranıyla etkileşimi 


\subsection{Betonun Kesme Dayanımına Katkısı, $V_{c}$}

Kesme dayanımına beton katkısı, kesme kuvveti ile kesme donatısı katkısının farkı alınarak saptanmıştır. Kesme donatısı katkısı, eğik çatlak gözlenen bir numunede eğik çatlağı kesen enine donatılardaki deneysel iç kuvvetlerin bileşkesi olarak dikkate alınmıştır. Eğik çatlağı kesen herhangi bir enine donatıdaki iç kuvvet ise, deney sırasında ölçülen birim şekildeğiştirmeye bağlı belirlenen gerilme ile enine donatı toplam en kesit alanının çarpılmasıyla belirlenmiştir. Beton katkısının saptanmasında yararlanılan bu yaklaşım ile elde edilen sonuçları özetlenmeden önce, sonuçların doğruluğu üzerinde etkili olabilecek bazı hususların deneysel gözlem ve ölçümler ile tartışılması yerinde olur.

- Şekil 10'da, SN3.5/0.35YP1 isimli numunenin belirli bir enine donatısinda meydana gelen birim şekildeğiştirme geçmişi gösterilmiştir. Bu birim şekildeğiştirmeler, tersinir etkiyle iki yönde oluşan eğik çatlakların kesişim bölgesindeki enine donatıya ait özel bir durumdur. Şekilde yatay eksen kolon numunesine uygulanan yerdeğiştirmeyi göstermektedir. Şekilden de görüleceği üzere, yerdeğiştirme zorlaması -genelde- enine donatı birim şekildeğiştirmesinde artış meydana getirmektedir. Bu genel eğilim ileri hasar bölgesinde değişkenlik sergilemektedir. Daha açık bir ifadeyle, kolon numunesine uygulanan yerdeğiştirme talebi küçülmesine rağmen enine donatı birim şekildeğiştirmesinde artış meydana gelmektedir. Bu özel durumun, eksenel yükün eğik çatlakların kesişimi ile meydana gelen parçaları enine doğrultuda açılmaya zorlamasından kaynaklandı̆̆ değerlendirilmektedir. Kesme talebinden bağımsız olarak gerçekleşen böyle durumlardan itibaren beton katkısı belirlenmemiştir.

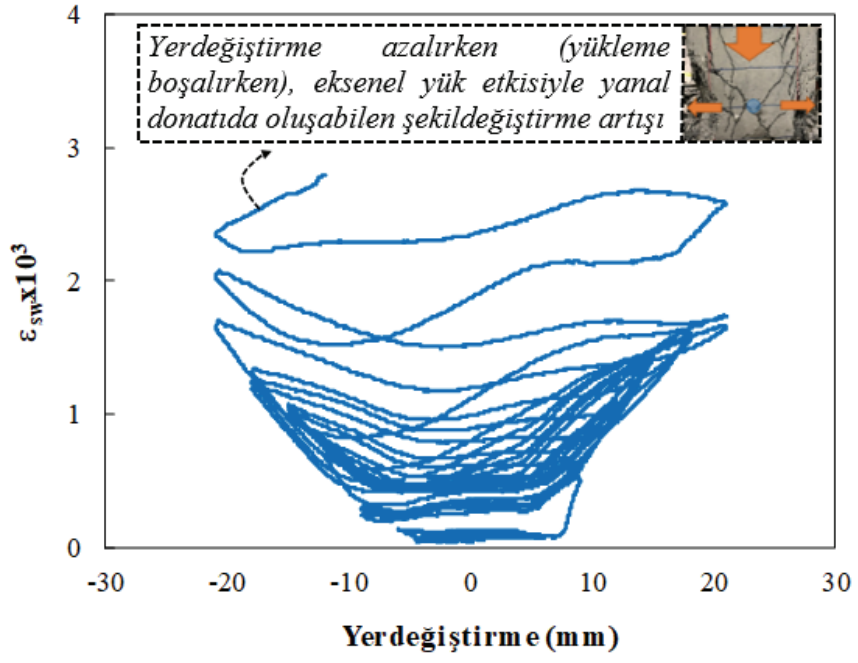

Şekil 10 - SN3.5/0.35YP1 deney numunesinde belirli bir seviyedeki enine donatıda deneysel birim şekildeğiştirme geçmişi

- Bilindiği üzere sargı donatı, betonda hem dayanım hem de -özellikle- birim şekildeğiştirme kapasitesini arttırmaktadır. Sargı etkisi olarak anılan bu etki, eğilme davranışı altında plastik mafsal bölgesinde -kesme davranışından bağımsız olarak- enine donatıda ilave birim şekildeğiştirme talebi oluşturacaktır. Bu ilave birim şekildeğiştirme 
talebinin belirsizliği, çalışmada betonun ve donatının kesme dayanımına katkılarının belirlendiği yaklaşımın sonuçları üzerinde bir belirsizlik doğuracağı açıktır. Sözü edilen belirsizliğin sonuçlar üzerindeki etkileri yorumlayabilmek amacıyla, Şekil 11'de bir kolon numunesi için farklı düzeylerde ölçülen enine ve boyuna şekildeğiştirme talepleri karşılaştırılmıştır. Şekilden de görüleceği üzere, boyuna donatıda ölçülen birim şekildeğiştirme talepleri temel yüzüne mesafe arttıkça azalma eğilimindedir. Eğilme momentindeki değişim göz önüne alındığında, bu değişim beklenen bir eğilimdir. Basınç bölgesinde boyuna donatı ekseni ile en dış sargılı beton lifi oldukça yakın olduğundan, sargılı beton birim kısalmalarında da benzer bir eğilim olduğu söylenebilir. Dolayısıyla temel seviyesine yakın enine donatılarda kesme kuvveti talebine bağlı enine birim şekildeğiştirme talebinin, eğik çatlağı kesen ve üst konumda yer alan diğer enine donatılara kıyasla daha yüksek olması beklenebilir (sargı etkisinin ilave talebiyle). Konsol deney düzeninde kesme etkisi eleman boyunca sabit olmasına karşın, kesme davranışı bakımından zorlama belirli bir kesitte beton ve enine donatı ile birlikte taşınmıştır. Kesme açısından kritik kesit olarak anılan bu kesit temel yüzüne yaklaşık $\mathrm{d} / 2$ mesafededir. Bu kesit ile temel arasındaki bölgede temele aktarılan kesme kuvveti ise doğrudan bir basınç çubuğu ile temele iletilmekte ve enine donatısı katkısına ihtiyaç duyulmamaktadır. Şekil üzerinde çeşitli seviyelerdeki enine donatı birim şekildeğiştirme talepleri, yukarıda eğilme ve kesme davranışına yönelik bilgilerle incelendiğinde; sargı davranışının ölçüm yöntemi sonuçlarına etkisinin ileri hasar bölgesinde ve genelde temel seviyesine yakın bölgelerdeki ölçümler için söz konusu olduğu söylenebilir.
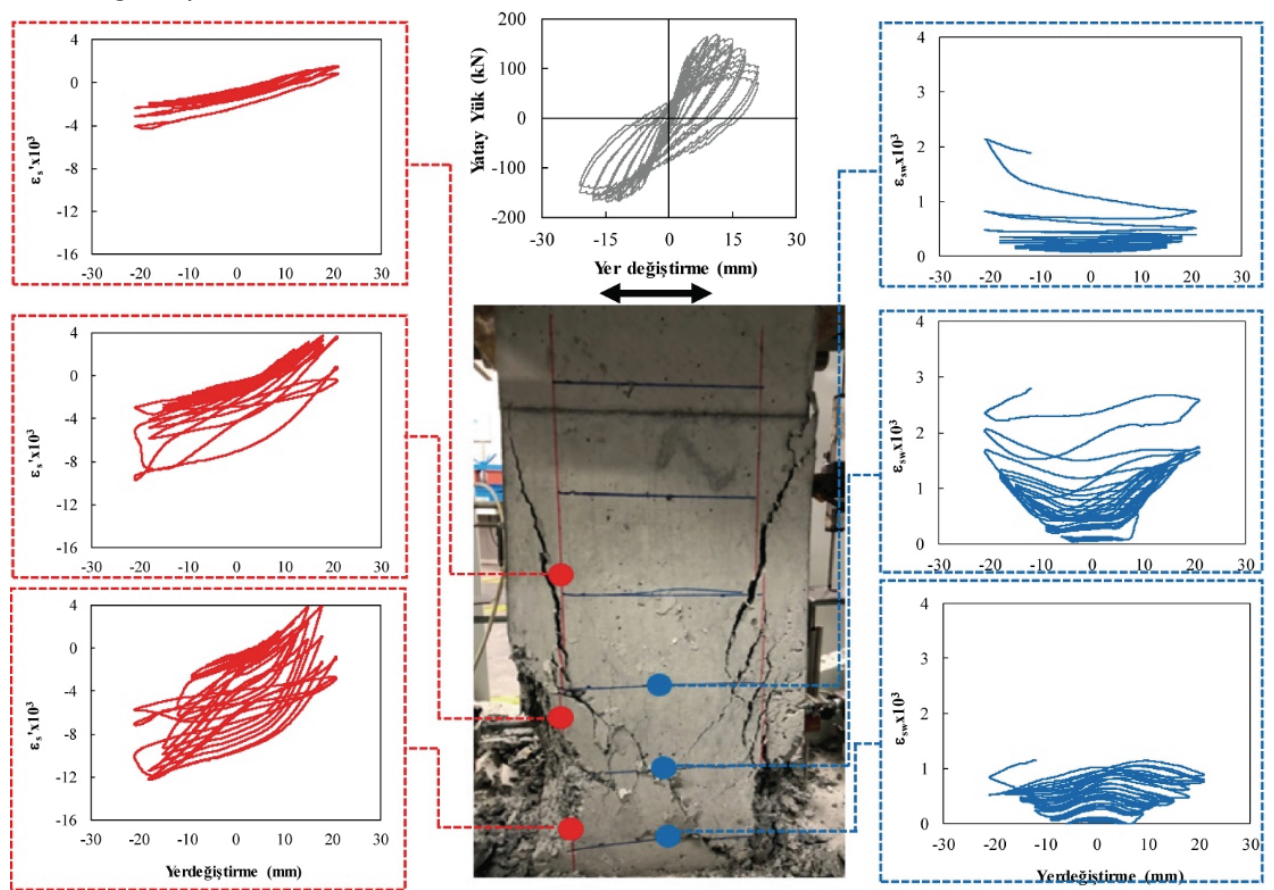

Şekil 11 - SN3.5/0.35YP1 deney numunesinde deneysel yük-yerdeğiştirme geçmişi ve çeşitli düzeylerdeki boyuna ve enine donatıların birim şekildeğiştirme geçmişleri 
- Bilindiği üzere boyuna donatı burkulması ileri bir hasar göstergesidir. Gerçekleşmesi durumunda enine donatıda belirgin bir ilave birim şekildeğiştirme talebi meydana getirir. Sözü edilen ilave talep Şekil 11'de verilen karşılaştırmalardan da görülebilir. Şekilde boyuna donatıda burkulma meydana gelmesiyle, yük-yerdeğiştirme ilişkilerindeki tekrarlı çevrimsel yükleme adımları arası belirgin bir düşüş, enine donatı birim şekildeğiştirme talebinde hızlı bir artış meydana gelmektedir. Kesme talebinden bağımsız olarak gerçekleşen böyle durumlar için, çalışmada enine donatı şekildeğiştirme talebiyle betonun ve donatının kesme dayanımına katkılarının belirlendiği ölçüm yöntemi kullanılması uygun olmayacağı söylenebilir. $\mathrm{Bu}$ nedenle çalışmada belirgin burkulma davranışı gözlendiği nokta sonrası beton katkısı belirlenmemiştir.

Şekil 12'de numunelerin deney sonu hasar durum fotoğrafları verilmiştir. Fotoğraflar üzerindeki eğik çatlaklar yöne göre $\mathrm{EC}_{+}$ve $\mathrm{EÇ.} \mathrm{olarak} \mathrm{isimlendirilerek} \mathrm{gösterilmiştir.} \mathrm{Ayrıca}$ fotoğraflar üzerinde numunelere uygulanan eksenel basınç gerilmesi ve çeşitli seviyedeki enine donatılarda meydana gelen birim şekil değiştirmeler de gösterilerek, ilave bilgi verilmeye çalışılmıştır. Enine donatı birim şekildeğiştirme değerleri $\left(\varepsilon_{\mathrm{sw}}\right)$ çevrimsel yükleme geçmişinde her bir yükleme adımındaki hedef maksimum yerdeğiştirme adımında ölçülen değerler olup, ölçümlerinin tamamı aynı işaretlidir. Şekil 12 'de ise yatay yükün işaret değiştirdiğinin gösterilmesi adına ters işaretli olarak gösterilmiştir.

Şekil 13'de kiriş numuneleri için kesme dayanımına beton ve kesme donatısı katkılarının yerdeğiştirme talebine göre değişimleri yük-yerdeğiştirme diyagramları üzerinde gösterilmiştir. Kolon numuneleri için ise benzer ilişkiler Şekil 14'den görülebilir. Bu ilişkilerde kesme donatısı katkısı, eğik çatlağı kesen enine donatı iç kuvvetlerin bileşkesi olup, enine donatı iç kuvvetleri deney sırasında meydana gelen birim şekildeğiştirme ölçümleri yardımıyla saptanmıştır. Diyagram üzerinde beton katkısına yönelik gösterilen deneysel sonuçlar, eğik çatlak gözlemi yapılan yerdeğiştirme talebinden itibaren gösterilmeye başlanmıştır. Eğik çatlak gözlenmeyen numunelerde ise beton katkısı belirlenememiş/gösterilmemiştir.

Şekil 13'de YP1 yükleme geçmişinin uygulandığ deney numunelerinde her iki eğilme yönünde de plastik mafsal (yön değiş̧iren plastik mafsal davranışı), YP2 yükleme geçmişinin uygulandığı numunelerde ise sadece bir eğilme yönünde de plastik mafsal (yön değiştirmeyen plastik mafsal davranışı) oluşmuştur. İsimlendirmede "KN" kullanılan numuneler normal, "KH" kullanılanlar ise yüksek mukavemetli beton ile imal edilmiştir. Şekil üzerinde sol tarafta yer alan diyagramlar a/d oranı 3.6, sağ taraftakiler ise a/d oranı 6.0 olan numuneler içindir. Deney kirişlerinin tamamında kesme donatısı katkısında artış eğilimi boyuna donatı akmasıyla belirginleşmektedir. Beton katkısındaki azalma eğiliminin ise örtü betonda ezilme gözlemi ile belirginleşmeye başladığı söylenebilir. Ayrıca YP1 yükleme geçmişinin uygulandığı kiriş numunelerinde beton katkısının ileri hasar bölgelerinde belirgin bir biçimde azaldığ 1 söylenebilir. Bu kirişlerde beton katkısının nerdeyse sıfirlandığı öteleme oran1, YP2 yükleme geçmişinin uygulandığı kiriş numuneleri için de bir sınır olarak alındığında, bu kirişlerdeki beton katkısındaki azalmanın daha az olduğu söylenebilir (yön değiştirmeyen plastik mafsal davranışı). Bilindiği gibi Türkiye Bina Deprem Yönetmeliği, sadece deprem yüklerinden oluşan kesme kuvvetinin depremli durumdaki toplam kesme kuvvetinin yarısından daha büyük olması durumunda, betonarme kirişlerde beton katkısı ihmal edilmektedir. Bu yaklaşım Şekil 13'de verilen beton 
katkılarıyla karşılaştırıldığında, Yönetmelik önerisinin YP1 yükleme geçmişinin uygulandığı kiriş numuneleri ve ileri hasar bölgeleri için yerinde bir yaklaşım olduğu, YP2 profilinin yüklendiği numuneler için daha ihtiyatlı kalabileceği söylenebilir.
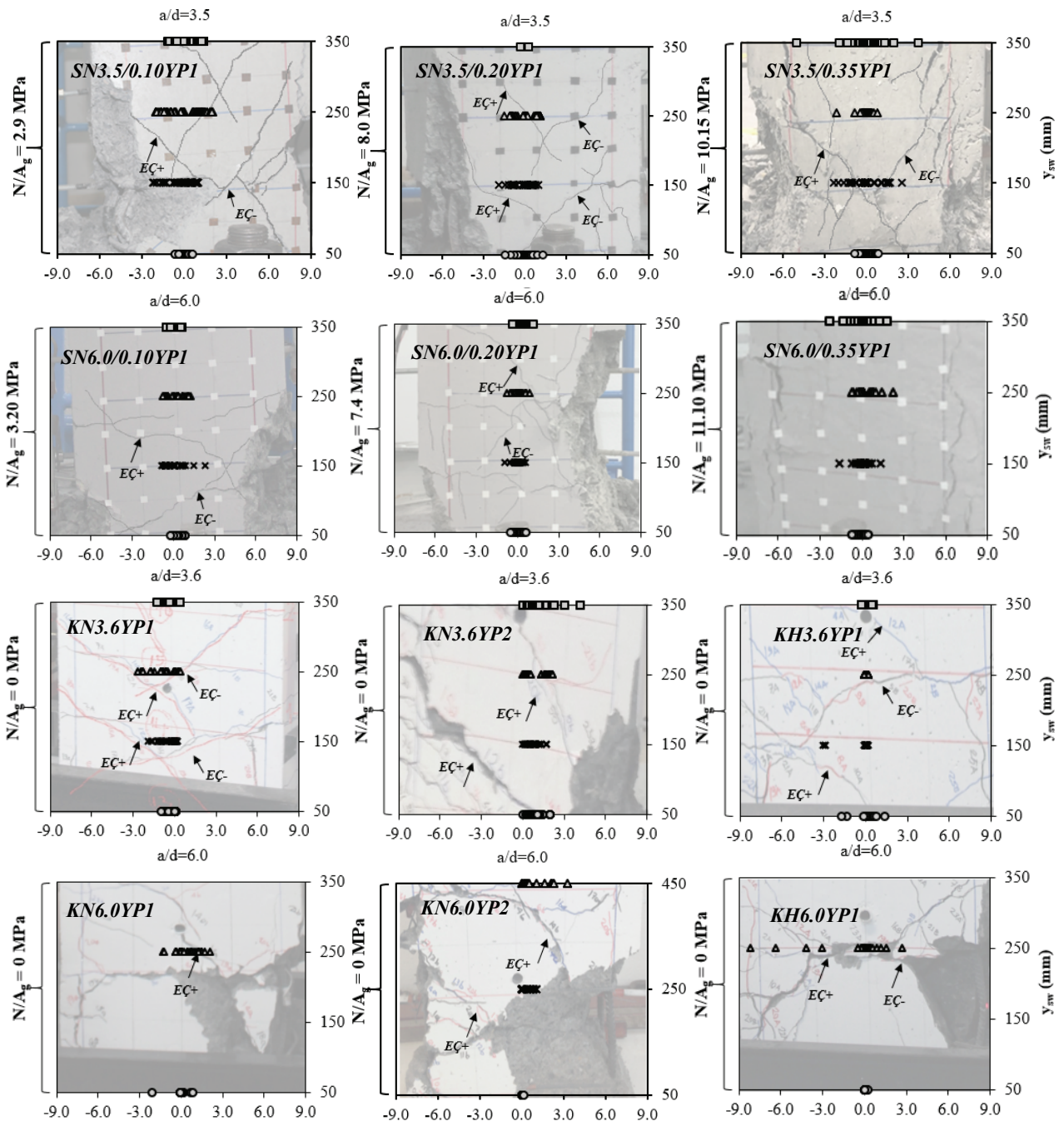

Şekil 12 - Kolon ve kiriş numunelerinin deney sonu hasar durumları

Şekil 14'de solda verilen diyagramlar a/d oran1 3.5, sağdakiler ise a/d oran1 6.0 olan kolonlar içindir. Eğik çatlak gözlenmeyen S6.0/0.35YP1 kolonunda beton katkıs1 gösterilmemiştir. Diğer kolonlarda eğik çatlak oluşmuş olup, kolon numunelerin tamamında kesme donatısı katkısında artış eğilimi boyuna donatı akmasıyla belirginleşmektedir. Bir başka ifadeyle plastik yer değiştirme talebiyle birlikte beton katkısında bir azalma eğilimi söz konusudur. Bilindiği üzere Türkiye Bina Deprem 
Yönetmeliği'nde kolonlarda betonun kesme dayanımına katkısını kirişler için tanımlanan şarta ek aynı zamanda kolon eksenel yükünün $0.05 \mathrm{~A}_{\mathrm{c}} \mathrm{f}_{\mathrm{ck}}$ değerinin altında olması durumunda ihmal edilmektedir. Karşılaştırmadaki kolonlarda eksenel yük belirtilen sınırın üzerindedir. Dolayısıyla Yönetmeliğin önerisi beton katkısının TS500-2000'de verilen bağıntı ile belirlenmesidir. Bu yaklaşımın özellikle plastik yerdeğiştirme talebi ve/veya a/d oranı artıkça beton katkısında görülen azalmayı yansıtamayacağı bir başka ifadeyle güvensiz kalabileceği söylenebilir.
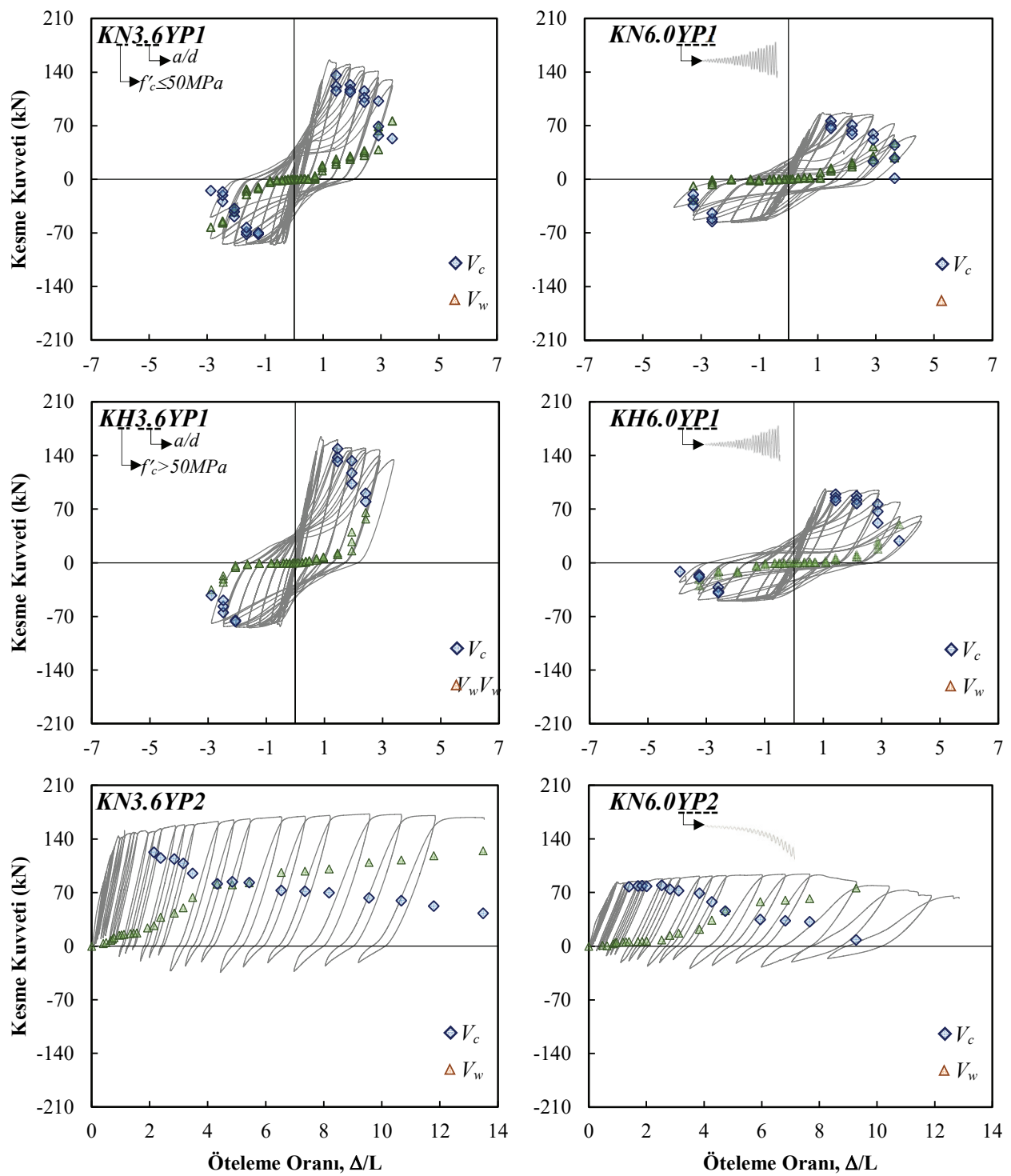

Şekil 13 - Kiriş numunelerinde beton $\left(V_{c}\right)$ ve enine donatınin $\left(V_{w}\right)$ kesme dayanımına katkllarınin yerdeğiştirme talebine göre değişimleri 

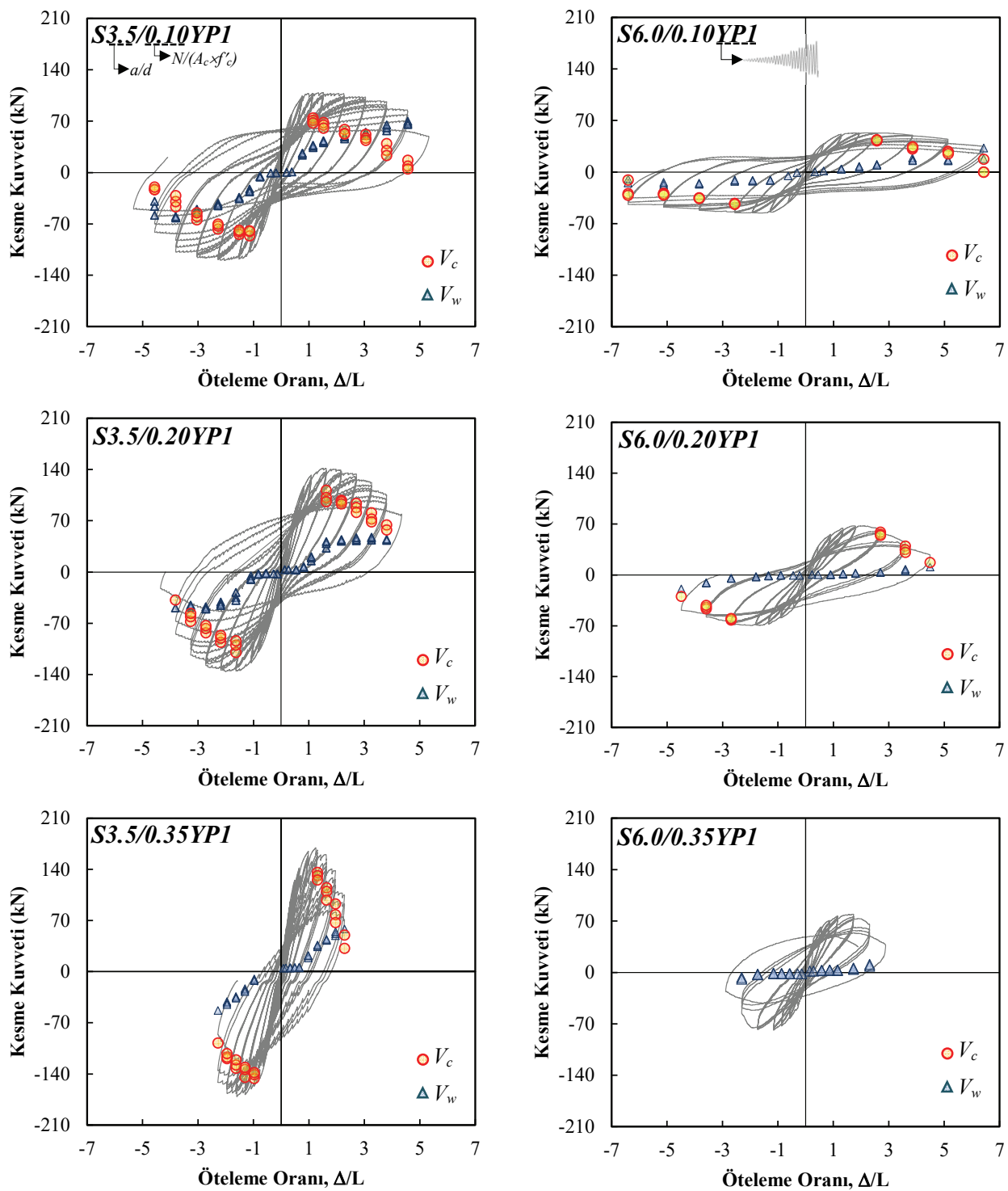

Şekil 14 - Kolon numunelerinde beton $\left(V_{c}\right)$ ve enine donatının $\left(V_{w}\right)$ kesme dayanımına katkılarının yerdeğiştirme talebine göre değişimleri

\subsection{Kesme Dayanımına Beton Katkısı Bağıntılarının Karşılaştırılması}

Çalışmanın bu bölümünde kesme dayanımına beton katkısı belirlenmesinde kullanılan çeşitli yaklaşımların sonuçları deneysel sonuçlar ile karşılaştırılacaktır. Karşılaştırmalarda kullanılan bağıntılar Çizelge 5'de verilmiştir. Tahmin modellerin deneysel sonuçlar ile 
karşılaştırılmaları Şekil $15^{\prime}$ de, istatistiksel olarak karşılaştırmaları ise Çizelge 6'da verilmiștir.

Çizelge 5 - Karşılaştırmada kullanılan kesme dayanımına beton katkısı modelleri

\begin{tabular}{|c|c|c|c|}
\hline Model [Referans] & Bağıntı & $\begin{array}{l}\text { Bağıntı } \\
\text { No }\end{array}$ & Açıklama \\
\hline ACI 318 [6] & $\mathrm{V}_{\mathrm{c}}=0.17 \sqrt{\mathrm{f}_{\mathrm{co}}}\left(1+\frac{\mathrm{N}_{\mathrm{u}}}{14 \mathrm{~A}_{\mathrm{g}}}\right) \mathrm{b}_{\mathrm{w}} \mathrm{d}$ & (1) & \multirow{2}{*}{$\begin{array}{lcr}\text { Kirişler için, sadece } & \text { deprem } \\
\text { yüklerinden } & \text { oluşan } & \text { kesme } \\
\text { kuvvetinin toplam } & \text { kesme } \\
\text { kuvvetinin yarısından daha büyük } \\
\text { olmasi; kolonlar için ise ek olarak } \\
\text { eksenel yükün } 0.05 \mathrm{~A}_{\mathrm{c}} \mathrm{f}_{\mathrm{ck}} \text { değerinin } \\
\text { altında olmas } & \text { durumunda, } \mathrm{V}_{\mathrm{c}}=0 \\
\text { alınmaktadır. } & \end{array}$} \\
\hline TBDY2018 [1] & $\mathrm{V}_{\mathrm{c}}=0.18 \sqrt{\mathrm{f}_{\mathrm{co}}}\left(1+0.07 \frac{\mathrm{N}_{\mathrm{u}}}{\mathrm{Ag}_{\mathrm{g}}}\right) \mathrm{b}_{\mathrm{w}} \mathrm{d}$ & (2) & \\
\hline $\begin{array}{l}\text { Aschheim ve } \\
\text { Moehle [16] }\end{array}$ & $\mathrm{V}_{\mathrm{c}}=0.3 \sqrt{\mathrm{f}_{\mathrm{co}}}\left(\mathrm{k}_{\mu}+\frac{\mathrm{N}_{\mathrm{u}}}{13.8 \mathrm{Ag}_{\mathrm{g}}}\right) \mathrm{b}_{\mathrm{w}} \mathrm{d}$ & (3) & $\begin{array}{c}\mu_{\Delta}=\Delta / \Delta_{\mathrm{y}} \\
\text { olmak üzere; } \\
\mathrm{k}_{\mu}=\left(4-\mu_{\Delta}\right) / 3\end{array}$ \\
\hline Priestley vd. [17] & $\mathrm{V}_{\mathrm{c}}=\mathrm{k}_{\mu} \sqrt{\mathrm{f}_{\mathrm{co}}} \mathrm{b}_{\mathrm{w}} \mathrm{d}$ & (4) & $\begin{array}{c}\mu_{\Delta}=\Delta / \Delta_{\mathrm{y}} \\
\text { olmak üzere; } \\
\mathrm{k}_{\mu}=0.29\left(\mu_{\Delta} \leq 2\right) \\
\mathrm{k}_{\mu}=0.10\left(\mu_{\Delta} \geq 4\right)\end{array}$ \\
\hline $\begin{array}{l}\text { Sezen ve Moehle, } \\
\text { [14] }\end{array}$ & $\mathrm{V}_{\mathrm{c}}=\mathrm{k}_{\mu}\left(\frac{0.5 \sqrt{\mathrm{f}_{\mathrm{co}}}}{\mathrm{a} / \mathrm{d}}\right) \sqrt{1+\frac{\mathrm{N}_{\mathrm{u}}}{0.5 \sqrt{\mathrm{f}_{\mathrm{c}}^{\prime} \mathrm{A}_{\mathrm{g}}}}} \mathrm{b}_{\mathrm{w}} \mathrm{d}$ & (5) & $\begin{array}{c}\mu_{\Delta}=\Delta / \Delta_{\mathrm{y}} \\
\text { olmak üzere; } \\
\left(0.7 \leq \mathrm{k}_{\mu}=1.15-0.075 \mu_{\Delta} \leq 1.0\right)\end{array}$ \\
\hline Muttoni [23] & $\mathrm{V}_{\mathrm{c}}=\frac{1 / 3}{1+\frac{120 \times \varepsilon_{0.6 \mathrm{~d}} \times \mathrm{d}}{16+\mathrm{d}_{\mathrm{g}}}} \sqrt{\mathrm{f}_{\mathrm{co}}} \mathrm{b}_{\mathrm{w}} \mathrm{d}$ & (6) & $\begin{array}{llr}\varepsilon_{0.6 \mathrm{~d}}: \text { Kesme } & \text { açısından } & \text { kritik } \\
\text { kesitte en dış basıç yüzüne } & 0.6 \mathrm{~d} \\
\text { derinlikteki } & \text { boyuna } & \text { birim } \\
\text { şekildeğiştirme ve } \quad \mathrm{dg}_{\mathrm{g}}: & \text { Beton } \\
\text { agregasını en büyük tane boyutu }\end{array}$ \\
\hline
\end{tabular}

Şekil 15'de Çizelge 5'de detayları özetlenen model sonuçları ile deneysel olarak meydana gelen sonuçlar diyagramlar üzerinde karşılaştırılmıştır. Diyagramlarda düşey eksen model tahminini yatay eksen deneysel beton katkısını göstermektedir. Diyagramlarda kiriş ve kolon numunelerine ait sonuçlar farklı işaretçiler kulllanılarak topluca gösterilmiştir. Karşılaştırmalardan da görüleceği üzere Çizelge 5'de verilen son iki modelin sonuçlarının deneysel sonuçlara yakın olduğu söylenebilir.

Karşılaştırılan model sonuçlarının istatistiksel değerlendirilmesi Çizelge 6'da özetlenmiştir. İstatistiksel değerlendirmeler standart hata (SH) ve korolasyon katsayıları (R) yardımıyla yapılmıştır. Standart hata ve korelasyon katsayısı ifadeleri aşağıda verilmiştir.

$$
\begin{aligned}
& \mathrm{SH}\left(\mathrm{V}_{\mathrm{c}}\right)=\sqrt{\frac{\sum\left(\mathrm{V}_{\mathrm{c}, \text { deney }}-\mathrm{V}_{\mathrm{c}, \text { model }}\right)^{2}}{\mathrm{n}}} \\
& \mathrm{R}\left(\mathrm{V}_{\mathrm{c}}\right)=\sqrt{\frac{\operatorname{Var}\left(\mathrm{V}_{\mathrm{c}, \text { deney }}, \mathrm{V}_{\mathrm{c}, \text { model }}\right)}{\sigma\left(\mathrm{V}_{\mathrm{c}, \text { deney }}\right) \times \sigma\left(\mathrm{V}_{\mathrm{c}, \text { model }}\right)}}
\end{aligned}
$$



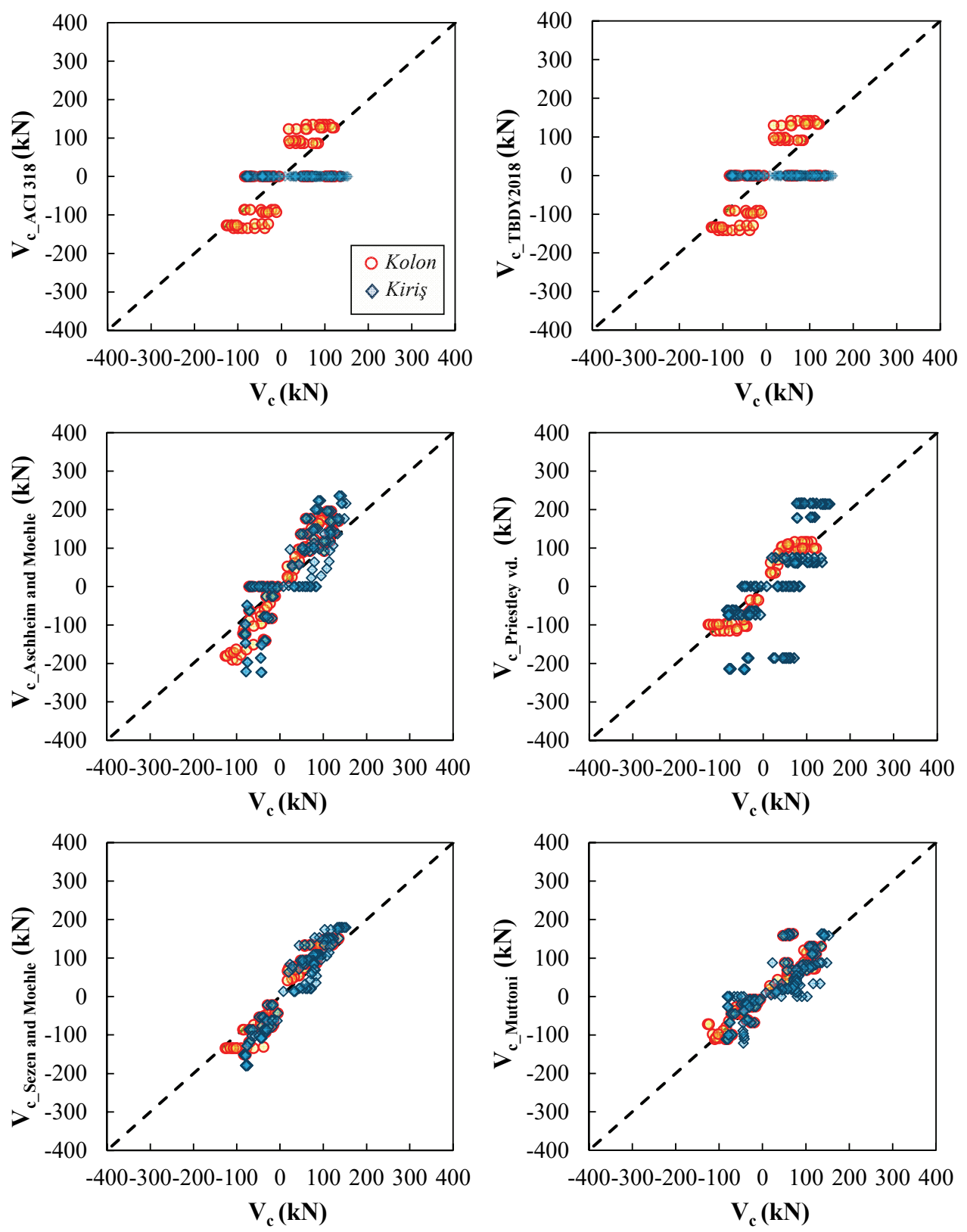

Şekil 15 - Beton katkı modelleri sonuçlarının karşılaştırılması

Çizelge 6'dan da görüleceği üzere Türkiye Bina Deprem Yönetmeliğinin kesme dayanımına beton katkısı tahmini kolon numunelerinde daha başarılıdır. Sezen ve Moehle [14] ve Muttoni [23] tarafından geliştirilen bağıntıların sonuçları ise hem standart hata (SH) 
hem de korelasyon katsayıları (R) bakımından çizelgedeki diğer bağıntılara kıyasla daha iyi sonuç verdiği söylenebilir.

Çizelge 6 - Beton katkı model tahminlerinin deneysel sonuçlar ile karşılaştırılması

\begin{tabular}{|l|c|c|c|c|c|c|}
\hline \multirow{2}{*}{ Referans } & \multicolumn{5}{c|}{ İstatistiksel Değerlendirme } \\
\cline { 2 - 7 } & \multicolumn{2}{|c|}{$\begin{array}{c}\text { Kiriş } \\
\text { numunelerinde }\end{array}$} & $\begin{array}{c}\text { Kolon } \\
\text { numunelerinde }\end{array}$ & \multicolumn{2}{c|}{$\begin{array}{c}\text { Kiriş ve kolon } \\
\text { numunelerde }\end{array}$} \\
\cline { 2 - 7 } & $\mathrm{SH}\left(\mathrm{V}_{\mathrm{c}}\right)$ & $\mathrm{R}\left(\mathrm{V}_{\mathrm{c}}\right)$ & $\mathrm{SH}\left(\mathrm{V}_{\mathrm{c}}\right)$ & $\mathrm{R}\left(\mathrm{V}_{\mathrm{c}}\right)$ & $\mathrm{SH}\left(\mathrm{V}_{\mathrm{c}}\right)$ & $\mathrm{R}\left(\mathrm{V}_{\mathrm{c}}\right)$ \\
\hline ACI318 [6] & 78.4 & 0 & 53.5 & 0.92 & 72.7 & 0.46 \\
\hline TBDY2018 [1] & 78.4 & 0 & 58.6 & 0.92 & 73.8 & 0.46 \\
\hline Aschheim ve Moehle [16] & 72.2 & 0.85 & 55.4 & 0.98 & 68.2 & 0.89 \\
\hline Priestley vd. [17] & 102.0 & 0.73 & 34.0 & 0.95 & 89.0 & 0.75 \\
\hline Sezen ve Moehle [14] & 48.6 & 0.96 & 36.3 & 0.97 & 45.7 & 0.96 \\
\hline Muttoni [23] & 41.0 & 0.85 & 20.5 & 0.96 & 36.7 & 0.88 \\
\hline
\end{tabular}

\section{SONUÇLAR VE ÖNERİLER}

$\mathrm{Bu}$ çalışmada, tersinir çevrimsel yük altında eğilme kırılmasıyla taşıma gücüne ulaşan betonarme kolon ve kirişlerde, betonun kesme dayanımına katkısı deneysel olarak incelenmiştir. Deney programındaki kiriş numuneleri için beton basınç dayanımı, plastik davranış biçimi, plastik mafsal çalışma biçimi ve kesme açıklığının faydalı yüksekliğe oranı; kolon numuneleri için ise eksenel yük düzeyi ve kesme açıklığının faydalı yüksekliğe oranı değişken olarak dikkate alınmıştır. Çalışmada betonun kesme kuvvetine katkısı, artan yerdeğiştirme talebine bağlı biçimde deneysel olarak gözlenmiş ve deneysel sonuçlar farklı çalışmaların sonuçlarıyla karşılaştırılmıştır. Sınırlı sayıda deney numunesi sonucu esas alınarak yapılan karşılaştırmalardan elde edilen temel sonuçlar aşağıda maddeler halinde sunulmuştur.

- Kiriş numunelerinde a/d oranının artması, kolon numunelerinde ise a/d oranının artması ya da eksenel yük düzeyinin azalması -beklendiği gibi- eğik çatlama dayanımında azalma meydana getirmesinin yanında, eğik çatlak oluşumu gözlenen yerdeğiştirme süneklik oranını da arttırmaktadır (Şekil 8 ve Şekil 9).

- YP1 isimli yükleme geçmişiyle zorlanarak çift yönlü plastik mafsal davranış1 sergileyen normal ve yüksek dayanımlı beton ile imal edilen kiriş numunelerinde, Türkiye Bina Deprem Yönetmeliğindeki $\mathrm{V}_{\mathrm{c}}=0$ kabulünün plastik yerdeğiştirme talebinin artmasıyla gerçekçi olduğu, plastik davranışın başlangıcında ise ihtiyatlı kaldığı söylenebilir (Şekil 13).

- YP2 isimli yükleme geçmişiyle zorlanarak tek yönlü plastik mafsal davranış1 sergileyen numunelerde, kesme kuvveti kalıcı pozitif yer değiştirme altında yön değiştirmektedir. Dolayısıyla kesme kuvvetinin yön değiştirmesi kesitte diğer eğilme yönünde bir plastik davranış ya da iki eğilme yönünde de betonda ezilme 
oluşumu gerçekleştirmemiştir. Kesme kuvveti yön değiştirdiği için $\mathrm{V}_{\mathrm{c}}=0$ alınması önerisinin, plastik mafsal davranışı yön değiştirmediği durumlar için ihtiyatlı kaldığı söylenebilir.

- Sabit eksenel yük etkisinde YP1 isimli yükleme geçmişiyle zorlanarak çift yönlü plastik mafsal davranışı sergileyen ve a/d oranı 3.5 olan kolon numunelerinde Türkiye Bina Deprem Yönetmeliğindeki $\mathrm{V}_{\mathrm{c}}$ tahmininin $\left(\mathrm{V}_{\mathrm{c}}>0\right.$ durumu) deneysel sonuçlara yakın olduğu söylenebilir. Plastik yerdeğiştirme talebinin artmasıyla, yönetmelik tahmini deneysel sonuçlara göre büyük gerçekleşmektedir. a/d oranı 6.0 ve eksenel yük düzeyi 0.1 ve 0.2 olan deney kolonlarında, a/d oranı 3.5 olan kolonlara göre eğik çatlağın daha büyük plastik yerdeğiştirme talebiyle ortaya çıktığı ve yönetmeliğin $\mathrm{V}_{\mathrm{c}}$ tahminin, plastik yerdeğiştirme talebiyle $\mathrm{V}_{\mathrm{c}}$ 'de görülen azalmayı yansıtamadığı söylenebilir.

- Çizelge 6'da yapılan karşılaştırmalarla, Sezen ve Moehle [14] tarafindan geliştirilen ve yerdeğiştirme süneklik oranına göre ifade edilen ve Muttoni [23] tarafından geliştirilen boyuna birim şekildeğiştirmeye bağlı ifade edilen bağıntı sonuçlarının, karşılaştırmada esas alınan diğer bağıntılara göre daha başarılı sonuçlar verdiği söylenebilir.

Basit ya da bileşik eğilme altında zorlanan betonarme elemanların eğilme davranışı, beton ve donatı çeliği için gerçekçi malzeme modellerine dayanan moment-eğrilik analizi yardımıyla belirlenebilir. Bu analiz ile moment ve kesit eğriliği ile birlikte kesitteki birim şekil değiştirme dağılımı da saptanmaktadır. Dolayısıyla bu dağılım yardımıyla Muttoni [23] tarafından geliştirilen bağıntıda yer alan ve kesme açısından kritik kesitte en dış basınç yüzüne $0.6 d$ derinlikteki boyuna birim şekildeğiştirme $\left(\varepsilon_{0.6 d}\right)$ de belirlenerek, betonun kesme dayanımına katkısı yaklaşık olarak hesaplanabilir. Ayrıca bu yaklaşım ile eleman ekseni boyunca kesme talebi sabit olup, plastik davranış talebi ya da birim şekildeğiştirme talebi azalan kesitler için betonun kesmeye katkısındaki değişkenlik (artış) göz önüne alınabilir. Dolayısıyla bu yöntem, Türkiye Bina Deprem Yönetmeliğinde tanımlanan çeşitli hasar sınır durumları için kesme dayanımının belirlenmesinde -mevcut $\mathrm{V}_{\mathrm{c}}$ yaklaşımı bir üst sınır olarak benimsenerek- kullanılabileceği değerlendirilmektedir.

\section{Teşekkür}

Bu çalışma, İstanbul Aydın Üniversitesi Bilimsel Araştırma Projeleri Koordinatörlüğü’nce BAP2015-01, BAP2016-01 ve BAP2017-01 numaralı projeler kapsamında desteklenmiştir. Proje çalışmasında değerli emekleri olan Prof. Dr. Metin GER (KHÜ)'e, İstanbul Aydın Üniversitesi İnşaat Mühendisliği Laboratuvarı teknik ekibine ve UTEST Malzeme Test Cihazlarına teşekkürlerimizi sunarız.

\section{Kaynaklar}

[1] Türkiye Bina Deprem Yönetmeliği, Afet ve Acil Durum Yönetimi Başkanlığ1, Ankara, 2018. 
[2] Deprem Bölgelerinde Yapılacak Binalar Hakkında Yönetmelik, Bayındırlık ve İskân Bakanlığı, Ankara, Mart 2007.

[3] Afet Bölgelerinde Yapılacak Yapılar Hakkında Yönetmelik, Bayındırlık ve İskan Bakanlığı, Ankara, Ağustos 1997.

[4] Aydemir C. and Zorbozan M., Uncertainty Analysis of Flexural Overstrength Ratio for RC Columns, ASCE Journal of Structural Engineering, V.138(8), 1042-1053, 2012.

[5] Aydemir C. ve Zorbozan M., Betonarme Kolonların Olası Eğilme Momenti Kapasitelerinin Belirlenmesi İçin Bir Yöntem, İMO Teknik Dergi, 23(112), 59035930, 2012.

[6] Building code requirements for structural concrete and commentary, ACI 318-14, ACI (American Concrete Institute), Farmington Hills, MI., 2014.

[7] Betonarme Yapıların Hesap ve Yapım Kuralları, TS-500, Türk Standartları Enstitüsü, Ankara, 2000.

[8] Design of Concrete Structures-Part 1-1: General Rules and Rules for Buildings, Eurocode-2, European Committee for Standardization, Brussels, 2004.

[9] Design of Concrete Structures, CSA A23.3-04, Canadian Standards Association, Mississauga, ON, 2004.

[10] ASCE-ACI Committee 426, The Shear Strength of Reinforced Concrete Members, Journal of the Structural Division, ASCE, V. 99, No. ST6, June 1973, pp. 1091-1187.

[11] Seismic Design Guidelines for Highway Bridges, Applied Technical Council, Report No. ATC-6, Berkeley, CA, 1981.

[12] Federal Emergency Management Agency, Prestandard and Commentary for the Seismic Rehabilitation of Buildings, FEMA 356, Washington, D.C., 2000.

[13] Moehle, J., Lynn, A., Elwood, K. and Sezen, H.0, Gravity load collapse of building frames during earthquakes, PEER Report: $2^{\text {nd }}$ U.S.-Japan Workshop on PerformanceBased Design Methodology for Reinforced Concrete Building Structures, PEER, Richmond, Calif., 2001

[14] Sezen, H. and Moehle, J.P., Shear strength model for lightly reinforced concrete columns, J Struct Eng, 130(11): 1692-1703, 2004.

[15] Wong Y.L, Pauley T. and Priestley M.J.N, Response of circular reinforced concrete column to multi-ductile seismic attack. ACI Structural Journal 90(2) 180-191, 1993.

[16] Aschheim, M., and Moehle, J. P. Shear strength and deformability of RC bridge columns subjected to inelastic displacements, UCB/EERC 92/04, University of California, Berkeley, 1992.

[17] Priestley M.J.N., Verma R., and Xiao Y. Seismic shear strength of reinforced concrete columns, J Struct Eng, 120(8): 2310-2329, 1994. 
[18] Pérez B.M. and Pantazopoulou S.J. Mechanics of concrete participation in cyclic shear resistance of RC, J Struct Eng, 124(6): 633-641, 1998.

[19] Lee, J.-Y. and Watanabe F., Shear deterioration of reinforced concrete beams subjected to reversed cyclic loading, ACI Struct J, 100(4): 480-489, 2003.

[20] Elwood K.J. and Moehle J.P, Axial capacity model for shear- damaged columns, ACI Struct J, 102(4): 578-587, 2005.

[21] Arslan, G., Shear strength of reinforced concrete frame members under cyclic loads Ph.D. thesis, Yıldız Technical University, 2005.

[22] Kowalsky M.J., Priestley M.J.N., Improved analytical model for shear strength of circular reinforced concrete columns in seismic regions, ACI Struct J, 97(3):388-96, 2000.

[23] Muttoni, A., "Shear and Punching Strength of Slabs without Shear Reinforcement," Beton-und Stahlbetonbau, V. 98, 2003, pp. 74-84.

[24] Aydemir C., Aydemir M.E., Betonarme Kirişlerin Hasar Sınırlarının Deneysel Gözlemlerle İrdelenmesi, IMO Teknik Dergi, 28(4), 8023-49, 2017.

[25] Aydemir C., Eser Aydemir M., ve Yıldırım P., Belirgin Düşey Yük Etkisindeki Betonarme Kirişlerin Çevrimsel Yükler Altındaki Davranışı Üzerine Deneysel Bir İnceleme, IMO Teknik Dergi, 31(1), 9683-9709, 2020.

[26] Aydemir C., Eser Aydemir M., Experimental Research on Reversing and Nonreversing Plastic-Hinge Behavior for RC Beams, J Struct Eng, 146(7), 2020.

[27] Aydemir C., Döşeme Donatılarının İç Aks Kirişlerinin Negatif Moment Kapasitesi Üzerine Etkisi, IMO Teknik Dergi, 24(1), 6279-6306, 2013.

[28] Cansız S., Aydemir C., and Arslan G., Comparison of displacement capacity of reinforced concrete columns with seismic codes, Advances in Concrete Construction, 8(4), 295-304, 2020.

[29] Gião R., Lúcio V., and Chastre C., Assessing the behaviour of RC beams subject to significant gravity loads under cyclic loads, Engineering Structures, Vol. 59, 512-21, 2014. 